\title{
Treaty No. 9 and the Question of "Unceded" Land South of the Albany River in Subarctic Ontario, Canada
}

\author{
Stephen R.J. Tsuji ${ }^{1}$ and Leonard J.S. Tsuji ${ }^{2}$
}

(Received 24 September 2020; accepted in revised form 12 March 2021)

\begin{abstract}
The James Bay Treaty-Treaty No. 9 was unique among the numbered treaties of Canada in that there was a need for the concurrence of the Province of Ontario. Last-minute negotiations by the Dominion of Canada to gain said concurrence led to an agreement with the Province of Ontario, and this agreement became part of the Treaty No. 9 package at Ontario's insistence. However, since the agreement was not executed until after the Treaty No. 9 expedition had left for the field, an incomplete Treaty No. 9 package that lacked the agreement was presented to and signed by the First Nation groups in 1905. Furthermore, spaces had been left in the vellum copies of Treaty No. 9 and the agreement to add in the date of the agreement when fully executed. In the spaces that were left for this purpose, the date of the agreement was backdated to 3 July. This act of deception was suggested by the Treasurer of the Government of Ontario, A. Matheson in order to date of the agreement earlier than the date in the Treaty. Thus, the common law legality of the Treaty No. 9 package must be questioned, especially since officials of the Governments of Canada and Ontario left documentation of their deception. Without the agreement being attached as specified in the Treaty No. 9 document that left Ottawa in 1905, consideration of the terms of the agreement by the First Nation signatories of the treaty could not have occurred prior to signing. It follows that there exists a question of whether the land south of the Albany River was ever ceded in Treaty No. 9 from a common law perspective, unless documentation can be presented indicating that the complete Treaty No. 9 package was presented to the First Nation signatories; the written record indicates otherwise. In the end, the courts will have to decide the legality of Treaty No. 9 from a common law perspective.
\end{abstract}

Key words: Treaty No. 9; "an agreement dated the third day of July"; choosing of reserves; hydroelectric potential; unceded land; subarctic Ontario; Canada

RÉSUMÉ. Le Traité de la Baie James, ou Traité $n^{\circ} 9$, est unique comparativement aux autres traités numérotés du Canada en ce sens qu'il devait être accompagné de l'accord de la province de l'Ontario. Des négociations de dernière minute par le Dominion du Canada visant à obtenir ledit accord se sont conclues par une entente avec la province de l'Ontario, et cette entente a fait partie de l'ensemble du Traité $\mathrm{n}^{\circ} 9$ à la demande insistante de l'Ontario. Toutefois, puisque l'entente n'a été exécutée qu'après le départ de l'expédition du Traité $\mathrm{n}^{\circ} 9$ pour le terrain, l'ensemble du Traité ${ }^{\circ} 9$ était incomplet et il a été présenté ainsi, sans l'entente, aux groupes des Premières Nations qui l'ont signé en 1905. Par ailleurs, des espaces avaient été laissés dans les exemplaires sur vélin du Traité $n^{\circ} 9$ et de l'entente afin de permettre l'ajout de la date de l'entente une fois entièrement exécutée. Dans les espaces laissés à cette fin, la date de l'entente a été antidatée au 3 juillet. Cette supercherie avait été suggérée par le trésorier du gouvernement de l'Ontario, A. Matheson, afin que la date de l'entente soit antérieure à la date du traité. Par conséquent, il y a lieu de mettre en doute la légalité de l'ensemble du Traité $\mathrm{n}^{\circ} 9$ en vertu de la common law, surtout parce que les représentants des gouvernements du Canada et de l'Ontario ont laissé des documents attestant de leur supercherie. Puisque l'entente n'était pas jointe au document du Traité no 9 qui est parti d'Ottawa en 1905, comme stipulé, les signataires du Traité faisant partie des Premières Nations n'ont pas pu prendre connaissance des modalités de l'entente avant d'apposer leur signature. Il faut donc se poser la question à savoir si les terres au sud de la rivière Albany ont vraiment été cédées en vertu du Traité $\mathrm{n}^{\circ} 9$ du point de vue de la common law, à moins que des documents ne soient présentés selon lesquels l'ensemble complet du Traité no 9 a été remis aux signataires des Premières Nations. Pour l'instant, les écrits attestent du contraire. Au bout du compte, c'est aux tribunaux qu'il incombera de décider de la légalité du Traité no 9 en vertu de la common law.

Mots clés : Traité no 9; « une entente datée du troisième jour de juillet »; choix des réserves; potentiel hydroélectrique; terres non cédées; Ontario subarctique; Canada

Traduit pour la revue Arctic par Nicole Giguère.

\footnotetext{
${ }^{1}$ Corresponding author: School of Environmental Studies, Queen's University, Kingston, K7L 3N6 Ontario, Canada;

20srjt@queensu.ca

${ }^{2}$ Department of Physical and Environmental Sciences, University of Toronto Scarborough, 1265 Military Trail, Toronto, Ontario M1C 1A4, Canada

(C) The Arctic Institute of North America
} 
(a)

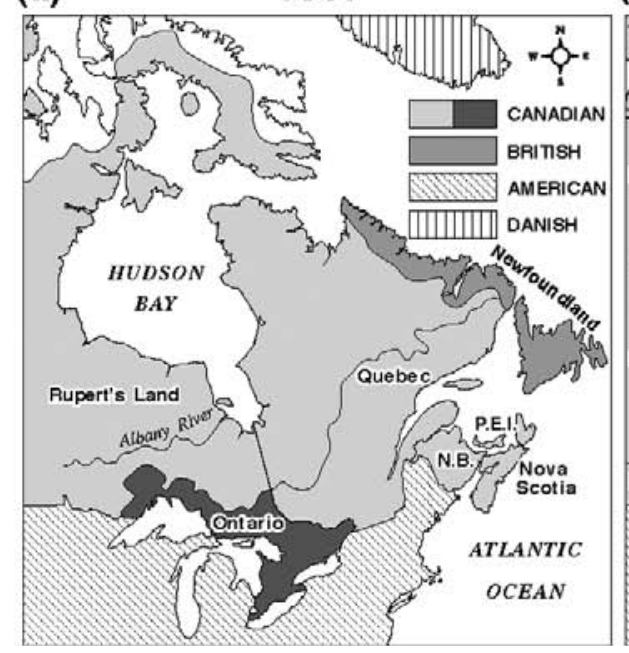

(b)

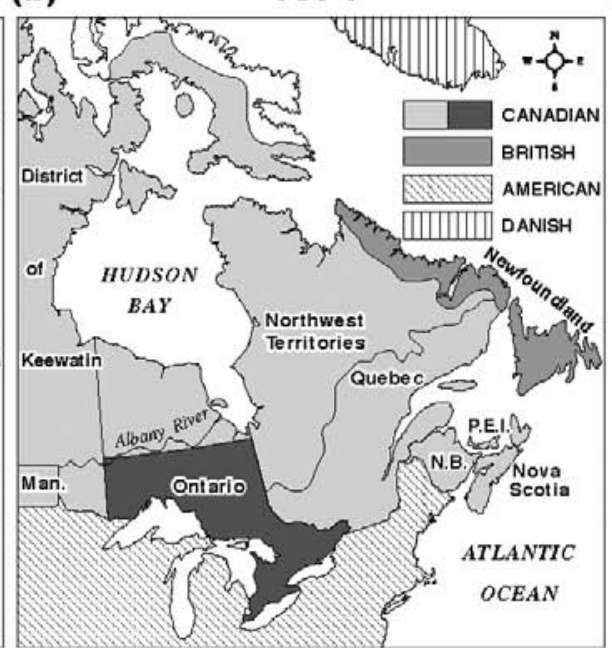

(c)

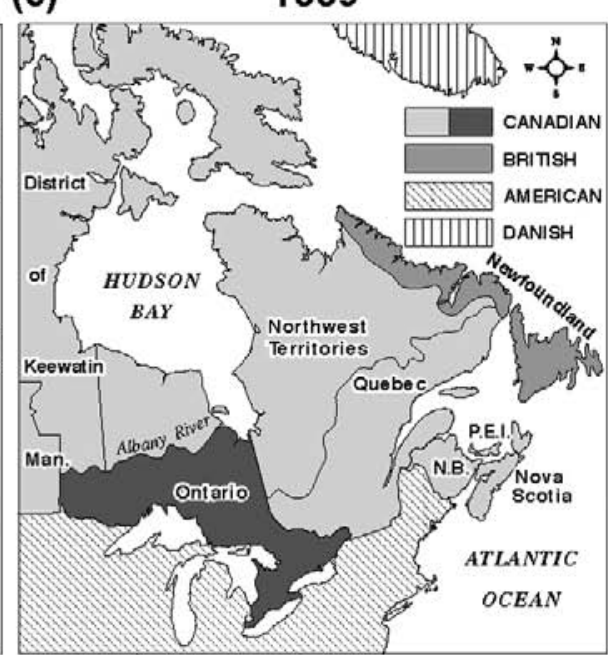

FIG. 1. The changing boundaries of the Province of Ontario: (a) the original boundaries at the confederation of the four provinces in 1867 to form the Dominion of Canada; (b) boundaries extended in 1874; and (c) further extension of Ontario's boundaries after the Canada (Ontario Boundary) Act, 1889 (Ontario, 1914), necessitating the need for Treaty No. 9 (from Tsuji et al., 2016 and Government of Ontario, 2019).

\section{INTRODUCTION}

In 1867, when the Dominion of Canada was created, the Province of Ontario was only a fraction of the size of present-day Ontario (Government of Ontario, 2019; Fig. 1). The landmass of Ontario would be increased incrementally through legislation (Canada (Ontario) Boundary Act, 1889 [Ontario, 1914], the Ontario Boundaries Extension Act (Can., 1912) [Ontario, 1980]), and the signing of treaties with Indian groups (CIRNAC, 2021). Indian is the term historically used in government documents for First Nations people. Indian lands needed to be surrendered through consent, that is, ceded or purchased because the British Government positioned that Indians held rights to land in North America (The Royal Proclamation of 1763, Henry, 2006). Of the numbered treaties signed with First Nations groups during the time period 1870-1930 (CIRNAC, 2021), Treaty No. 9 (1905) and its Adhesions were unique in that one of the treaty commissioners was nominated by and represented the Government of Ontario (Scott et al., 1905). The Dominion of Canada made this accommodation because Canada required the concurrence of the Government of Ontario for any treaties with respect to Indian lands in Ontario in the post-1894 period after Ontario won the St. Catherine's Milling decision (Drake, 2018). This requirement led to the last-minute negotiations with Ontario in order to obtain their concurrence with respect to Treaty No. 9 and is one of the reasons why so much controversy has been associated with Treaty No. 9 (1905) and its Adhesions (see e.g., Tsuji et al., 2016; Tsuji and Tsuji, 2021).

Although much has been written about Treaty No. 9 covering a variety of topics and perspectives (e.g., Scott et al., 1905; Scott, 1906; Long, 1978; Titley, 1986; Calverley, 2006; Tsuji et al., 2009, 2020a; Armstrong, 2013; Tsuji and Tsuji, 2021), very little has been written about the agreement between the Dominion of Canada and the
Province of Ontario dated the third of July. This third of July agreement (hereafter referred to as the Agreement) forms part of Treaty No. 9, as detailed in the text of Treaty No. 9 (1905). What has been written about the Agreement referred to its actual content (e.g., Long, 2010; Armstrong, 2013) and to several oral history and written records, which revealed that the First Nation signatories of Treaty No. 9 were not informed of the negotiations between Canada and Ontario with respect to Treaty No. 9 (e.g., Armstrong, 2008). Although Treaty No. 9 researchers noted that the date of the Agreement was backdated to the third of July (e.g., Long, 2010; Armstrong, 2013; Tsuji and Tsuji, 2021), analysis of the Agreement and associated Treaty No. 9 text was limited and not carried further. Here, we will be the first to examine the question of unceded land from a common law perspective in northern Ontario south of the Albany River related to Treaty No. 9 (1905) and the Agreement between the Dominion of Canada and Province of Ontario. We begin by presenting an Indigenous land perspective with respect to northern Ontario.

\section{LAND IN NORTHERN ONTARIO: AN INDIGENOUS PERSPECTIVE}

When there is more than one way of knowing, all ways should be considered to get a better understanding of complex issues, such as the concept of "land" (Tsuji and Ho, 2002; Moose Cree First Nation, 2009). The passage below gives a glimpse of the way that James Bay Cree view the land:

We love our land and have a special, sacred attachment to it. Our philosophy is we believe that we must care for the land as it has cared for us ...The land is the sacred resting places of our ancestors and together, forms our 
collective cultural memory and oral history... Water is the source of our life and is one of the most valued elements in our environment. Clean water contributes to spiritual, mental and physical wellbeing. We've always been able to trust its refreshment, nourishment and nutrients... Our ancestors knew that clean air is also needed in a healthy environment.

(Moose Cree First Nation, 2009:4-5)

By contrast, colonizers view the land as something to be developed and exploited for profit. This view is why the Government of Ontario, industry, and non-Indigenous Ontarians in general have long perceived northern Ontario as the "last frontier" or "an untouched land" (Hunter, 2009; J. Solomon, 2009; F. Beardy, 2009; see Supplementary Table S1 for full quotes by First Nations' leadership) awaiting to be settled and developed. While it is true that vast resources exist in the "untouched" hinterland of northern Ontario (Gardner et al., 2012), the Indigenous people who have lived there for millennia have utilized the whole region wisely according to Indigenous laws (Hunter, 2009; F. Beardy, 2009; Table S1) and codes of conduct (Tsuji and Nieboer, 1999; Tsuji et al., 2011; Whitelaw et al., 2012); thus, the land only appears to be untouched (F. Beardy, 2009; J. Solomon, 2009; Table S1). The land has to be respected and utilized sustainably, so that it is healthy for future generations (Babin, 2009; Hunter, 2009; Table S1).

It should be emphasized that from an Indigenous perspective: "We don't own the land, and we never did" (Mushkegowuk Council, 2021). Rather "the people are connected to the land. First Nations people are stewards of the land; it's part of us." (Keeter Corston, Chief Chapleau Cree First Nation, 2009:955). Additionally, First Nations' relationships with the land are reciprocal:

Our concepts of preserving Mother Nature...We are one with the land, we depend on it to feed our families, and we have thousands of years of intergenerational experience with how to live in harmony with the land and preserve it, not destroy it in a few years [through development].

(Sam McKay, Band Councilor Kitchenuhmaykoosib Inninuwug [Big Trout Lake First Nation], 2009:912)

From their worldview, if First Nations did not own the land, they could not have surrendered or ceded their homelands in northern Ontario through the signing of Treaty No. 9 (Table S2). As noted by Armstrong (2008: Executive Summary): "For the Ojibway and Cree people [of northern Ontario], this notion of 'giving up' or surrendering land was a totally foreign concept." However, the act of sharing is foundational to James Bay Cree culture (Tsuji and Nieboer, 1999; Tsuji et al., 2020b), which is why signatories of Treaty No. 9 contend that they only agreed to share the land (e.g., "Sharing the Land: A Mushkegowuk Treaty Awareness Initiative," Mushkegowuk Council, 2021; Table S2) external to their reserve land (Macklem, 1997).
However, some First Nations assert that they never even agreed to share their homelands because they never signed Treaty No. 9 (Hall, 2009, Table S2; see Tsuji and Tsuji [2021] for a more complete discussion of this issue).

Further, land stewardship was considered a right bestowed upon them by the Creator (Andrew Solomon, 2009, Chief Fort Albany First Nation); that is, an inherent right. According to Stan Beardy, Grand Chief Nishnawbe Aski Nation, a Tribal Council of 49 First Nations in northern Ontario,

The north is our homeland and we govern and protect it through our inherent right, given to us by the Creator. Since time immemorial, our people have exercised our inherent right and protected the lands. That is why they are still in pristine condition. And we will continue to protect our lands for future generations.

(Stan Beardy, Grand Chief Nishnawbe Aski Nation, 2009:828)

Indigenous inherent rights beyond constitutional rights have recently been acknowledged in Canada (King and Pasternak, 2018). The Government of Canada purports that:

The new policy will recognize Indigenous lawmaking power; their inherent rights to land; and, in many instances, title within their traditional territories. In all, the legislation and policy will support the implementation of the new United Nations Declaration on the Rights of Indigenous Peoples Act.

(CIRNAC, 2018)

Nonetheless, the complexities of Aboriginal title and the private property issue will require the abandoning of absolutes with respect to common law, constitutional law, and Indigenous law in order to find a solution acceptable to all parties involved (Borrows, 2015). Lastly, Bill C-15 (2021), An Act respecting the United Nations Declaration on the Rights of Indigenous Peoples, received first reading on 3 December 2020 in the House of Commons of Canada. Bill C-15 when (or if passed with amendments) will implement the United Nations Declaration and will hopefully provide a viable framework for Canada and its Indigenous peoples to move forward (Department of Justice Canada, 2021).

\section{BACKGROUND}

\section{The Ontario Boundary Extension of 1889}

In 1884, the Judicial Committee of the Imperial Privy Council extended the boundaries of the Province of Ontario westward and northward to the Albany River; this boundary extension was enacted through The Canada (Ontario Boundary) Act, 1889 (Ontario, 1914; Fig. 1). Due to increasing development pressure (e.g., prospecting, railway construction, and resulting settlement) in this newly 
acquired northern region of Ontario, Indian title needed to be surrendered or ceded, while non-treaty Indians wanted their way-of-life protected from this encroachment (Macrae, 1901). Also, it should be noted that "Indians, and Lands reserved for the Indians" (Section 91(24)) fell under the jurisdiction of the Government of Canada as specified in the division of powers in the Canadian Constitution Act, 1867. In this context, a memorandum from J. Macrae (1901:1), Office of the Inspector of Indian Agencies and Reserves, Government of Canada, was sent to the Superintendent General of Indian Affairs, Canada, outlining unsurrendered land (Fig. 2). The Macrae (1901) map (Fig. 2) shows unceded land in both northern Ontario and Quebec; the northern borders being the Albany River in Ontario, and the James Bay shoreline in Ontario and Quebec. This map was the starting point for discussions of the land to be considered for Treaty No. 9 (Tsuji and Tsuji, 2021).

\section{The Province of Ontario and the Need for Concurrence}

Even at these early stages of discussion of what would become the James Bay-Treaty No. 9 (hereafter cited as Treaty No. 9), the need for concurrences of the provincial governments of any treaty covering the area in Macrae's map was recognized. Indeed, J. McLean (1901), Secretary of Indian Affairs, Canada, sent a memorandum to R. Rimmer, Law Clerk, Indian Affairs, asking for a legal opinion on whether Ontario and Quebec needed to be included in the surrender of the land demarcated in the Macrae (1901) map and if a surrender of said land was desirable by Canada. Rimmer's (1901:3) report clearly recommends the concurrence of the provinces taking into account the "St. Catherines Milling Company case [where the Government of Canada lost to the Province of Ontario] ...I think the consent of each Province should certainly be obtained...view to seeking the concurrence of the provincial governments [Ontario and Quebec]."

Although Rimmer's legal opinion was clear that concurrences should be obtained from both Ontario and Quebec, what was lacking was any discussion on what form the concurrences should take (Tsuji and Tsuji, 2021). In the final version of a memorandum from F. Pedley, Deputy Superintendent General of Indian Affairs to C. Sifton, Minister of the Interior, and Superintendent General of Indian Affairs, Canada, it was specified that

So far as the Indians of Quebec are concerned, it is suggested that no treaty should be made with them or that any Quebec Indians living temporarily in Ontario should be included in the Ontario treaty [Treaty No. 9].

(Pedley, 1903:5-7)

Thus, with Quebec removed from the discussion, the Province of Ontario's concurrence was the only impedance to Treaty No. 9 at the inter-governmental level.

\section{METHODS}

We conducted a comprehensive search online and onsite at Library and Archives Canada (Ottawa, Ontario) and online at Archives of Ontario for any material related to Treaty No. 9 and associated agreements between the Dominion of Canada and the Province of Ontario. In addition, academic databases and other printed and online material were searched for relevant material. Data were extracted for evaluation from the following sources: Treaty No. 9 and associated agreements, maps, Treaty No. 9 reports and photographs, correspondence (including telegrams), draft documents, memorandums, books, published Indigenous oral history, relevant PowerPoint presentations, the film "Trick or Treaty" based on Treaty No. 9 and featuring interviews with First Nations-elected leaders (Obosawin, 2014), Treaty No. 9-Commission articles and diaries, and Treaty No. 9 reserve-survey correspondence. Particular attention was given to the timing of Dominion of Canada (i.e., federal) Orders-in-Council: "a legal instrument...made on the recommendation of the responsible [elected] Minister of the Crown and take[s] legal effect only when signed by the [appointed] Governor General [of Canada]...[Orders-in-Council were used in] the disposition of Aboriginal lands" (LAC, 2019). Similar to federal Orders-in-Council, provincial Orders-in-Council refer to: "a legal order made by the [appointed] Lieutenant Governor [of Ontario], on the advice of the Premier [elected leader of the Province of Ontario] or a Minister [of the Government of Ontario]" (Government of Ontario, 2020). Qualitative analyses included manual coding and deductive thematic analysis, a template organizational approach. These analyses were followed by an inductive analysis, where themes emerged from the data itself (Fereday and Muir-Cochrane, 2006); this data analysis was also iterative.

\section{RESULTS AND DISCUSSION}

\section{Canada-Ontario Initial Negotiations}

On 30 April 1904, Pedley sent a letter to E. Davis, Commissioner of Crown Lands, Ontario, stating that

this Department [Indian Affairs] proposes at as early a date as possible to negotiate a treaty with the Indians whose habitat lies North of the height of land between the boundaries of the tract surrendered by the Robinson Treaties of 1850, and the Northern and Eastern boundaries of the Province of Ontario.

(Pedley, 1904a:1)

In addition, Pedley's letter provided details on the stipulations of the treaty, and the urgency of a response (Table S3). A. White, Assistant Commissioner of Crown Lands, Ontario acknowledged receipt of Pedley's letter on 2 May 1904 and responded that the treaty matter "will receive 


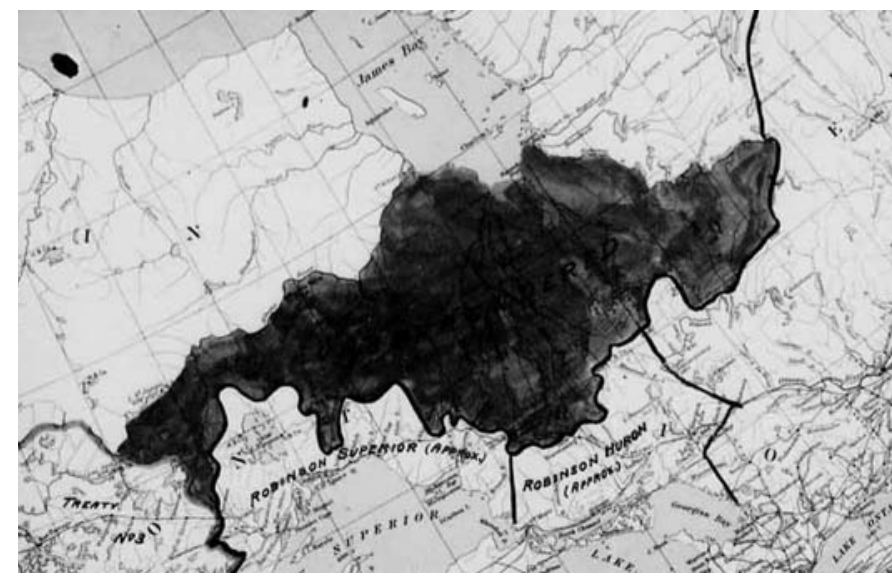

FIG. 2. Macrae's (1901) map of unsurrendered or unceded land (shaded area) in Ontario and Quebec, Canada.

the early attention of the Commissioner" (White, 1904a:1). White's (1904b:1-3) response on May 30 to Pedley's treaty proposal was adversarial in tone:

I have to call your attention to certain matters...By the sixth paragraph of the agreement made on the 16th April, 1894, between the Government of Canada and the Government of Ontario, it was provided, 'that any future treaties with the Indians in respect of territory in Ontario to which they have not hitherto surrendered their claim aforesaid (as in the agreement stated) shall be deemed to require the concurrence of the Government of Ontario'...The Government of Ontario does not concede that without its concurrence...the Department of Indian Affairs can promote a Treaty with Indians, placing the financial responsibility undertaken as well as the providing of reserves upon the Province...premature to enter into the negotiation which you letter suggests.

Although Pedley (1904b:1) reported in a memorandum dated 10 June 1904 to Sifton that "the Province of Ontario disclaims any responsibility in a treaty made without its concurrence," he was still optimistic that the Treaty No. 9 expedition could occur in August 1904. In Pedley's letter dated 24 June 1904, in an effort to placate White, Pedley explained:

The purpose of my communication of the 30th April was to lay the matter duly before your Government [of Ontario] with the hope of obtaining concurrence in the proposed action. The terms laid down upon which the treaty might be based are the maximum terms...offered to the Indians.

Although no definite arrangements have been made it is clear that during the month of August next [1904] it will be possible to treat with the Indians of [the most southern posts] ... The adherence to the treaty from the remaining Indians of the district could be taken during the summer of 1905 .

(Pedley, 1904c:1-2)
Ontario's response was not forthcoming; Pedley's optimism was misplaced. Although Indian Affairs' request for funds from the Government of Canada for a 1904 Treaty No. 9 expedition had been approved (Scott, 1905a), there was no Treaty No. 9 field expedition in August of 1904 without the concurrence of Ontario.

It was not until the following year on 27 February 1905, that Pedley (1905a) wrote a follow-up letter to White asking about progress with respect to the Treaty No. 9 issue. However, the Government of Ontario had changed hands by this time from the Liberal Party to the Conservative Party on 8 February 1905 (Legislative Assembly of Ontario, 2020; Table 1). Similarly, there was a leadership change in the Government of Canada when Sifton resigned on 27 February 1905 (Dominion of Canada, 1905). Subsequently, the Prime Minister of Canada, Sir Wilfrid Laurier, took on the role of Acting Superintendent General of Indian Affairs on 13 March 1905 (Table 1). Thus, February of 1905 was a time of political change both provincially and federally (Table 1), which undoubtedly negatively impacted negotiations with respect to Treaty No. 9.

By 18 March 1905, D.C. Scott, Accountant for Indian Affairs, sent a memorandum to Pedley, expressing the urgency of the timelines for the 1905 Treaty No. 9 expedition:

Unless this matter is decided within the next two weeks it would hardly be possible to make the treaty this year as the Indians will have to be notified almost immediately. This is the second year that funds have been voted [by parliament] without any action being taken.

(Scott, 1905a:1)

On the same day, Pedley (1905b) sent a telegraph to White, asking for him to make an appointment on the Monday with the Commissioner of Crown Lands, J. Foy, who recently replaced A.G. Mackay in the position (Table 1).

Subsequently, Pedley (1905c:1-2) issued a memorandum on 27 April 1905, In Re James Bay Treaty to Sir Wilfrid Laurier, Acting Superintendent General of Indian Affairs (Table 1) and expressed his frustration in gaining the concurrence of Ontario with respect to Treaty No. 9:

If the arrangements depended solely on the Government of the Dominion [i.e., Canada] it may confidently be stated that the treaty would have been signed before this...The Government of Ontario has always shown a reluctance to come to a definite understanding upon this important matter and at the present writing conditions remain as unsettled as they were at the inception.

On 2 May 1905, Pedley (1905d) submitted a letter to E. Newcombe, Deputy Minister of Justice, Canada, and enclosed a draft Treaty No. 9 Order-in-Council report for his opinion. Newcombe (1905a:1) responded on 5 May 1905: 
TABLE 1. Chronology of Government of Ontario and Government of Canada elected members of parliament responsible for the James Bay Treaty-Treaty No. 9.

\begin{tabular}{|c|c|c|c|}
\hline Name & Political affiliation & Position & Time in office \\
\hline \multicolumn{4}{|l|}{ Government of Ontario ${ }^{1}$} \\
\hline Elihu James Davis & Liberal Party of Ontario & Commissioner of Crown Lands & 21 October 1899 to 22 November 1904 \\
\hline Alexander Grant Mackay & Liberal Party of Ontario & Commissioner of Crown Lands & 22 November 1904 to 8 February 1905 \\
\hline James Joseph Foy & Conservative Party of Ontario & Commissioner of Crown Lands & 8 February 1905 to 30 May 1905 \\
\hline Francis Cochrane & Conservative Party of Ontario & $\begin{array}{l}\text { Minister of Lands and Mines } \\
\text { (formerly known as the } \\
\text { Commissioner of Crown Lands) }\end{array}$ & 30 May 1905 to 27 April 1906 \\
\hline Francis Cochrane & Conservative Party of Ontario & $\begin{array}{l}\text { Minister of Lands and Mines } \\
\text { (formerly known as the } \\
\text { Commissioner of Crown Lands) }{ }^{2}\end{array}$ & 27 April 1906 to 12 October 1911 \\
\hline \multicolumn{4}{|l|}{ Government of Canada ${ }^{3}$} \\
\hline Clifford Sifton & Liberal Party of Canada & $\begin{array}{l}\text { Minister of the Interior and } \\
\text { Superintendent General of Indian Affairs }\end{array}$ & 17 November 1896 to 28 February $1905^{4}$ \\
\hline Wilfrid Laurier & Liberal Party of Canada & $\begin{array}{l}\text { Acting Minister of the Interior and } \\
\text { Superintendent General of Indian Affairs }\end{array}$ & 13 March 1905 to 7 April 1905 \\
\hline Frank Oliver & Liberal Party of Canada & $\begin{array}{l}\text { Minister of the Interior and } \\
\text { Superintendent General of Indian Affairs }\end{array}$ & 8 April 1905 to 6 November 1911 \\
\hline
\end{tabular}

${ }^{1}$ Legislative Assembly of Ontario (2020)

${ }^{2}$ Ministry of Government and Consumer Services (2020)

${ }^{3}$ Parliament of Canada (2020)

${ }^{4}$ Actual date of resignation 27 February 1905 (Dominion of Canada, 1905)

It appears to me that all that is needed from the Government of Ontario is its concurrence and consent to the conclusion of a treaty upon the proposed terms...I enclose also a fair copy of the draft report as revised.

Briefly, details of the draft Treaty No. 9 Order-in-Council included provisions for annuities (money paid annually to treaty Indians) and gratuities (one-time payment at the time of treaty signing), a specification that the Indians would choose the location of their reserve, a provision for the establishment of schools on reserves, and assurances that the concurrence of the Government of Ontario would be embodied in a provincial Order-in-Council (Newcombe, 1905a; see Table S3 for greater detail).

Newcombe's revised draft Treaty No. 9 Order-inCouncil was sent to Foy, Commissioner of Crown Lands, Ontario, on 8 May 1905 by Pedley (1905e). Foy never responded because he relinquished his position on 30 May 1905 (Legislative Assembly of Ontario, 2020; see Table 1 for timelines). In addition, a provincial act was passed in 1905 whereby the Department of Crown Lands became the Department of Lands and Mines, and the Commissioner of Crown Lands became the Minister of Lands and Mines (Ministry of Government and Consumer Services, 2020). Thus, F. Cochrane was appointed Minister of Lands and Mines, Ontario on 30 May 1905 to replace Foy (Legislative Assembly of Ontario, 2020; Table 1). Nonetheless, it was
Matheson, Provincial Treasurer, Ontario, who replied to Pedley on 1 June 1905:

This matter has been referred to me. I enclose your draft for an Order-in-Council which can be put through if approved by the Dominion Government. You will notice change in second item of consideration.

(Matheson, 1905a:1)

The Ontario-revised Order-in-Council changed item 2 whereby the Indians would no longer choose their reserve location - the commissioners would now decide, and one of the treaty commissioners would be appointed by the Government of Ontario (Matheson, 1905a; Table S3).

On 2 June 1905, Pedley (1905f) sent a memorandum to Laurier indicating his reasons for supporting the acceptance of the new terms and attached the draft Order-in-Council submitted by the Government of Ontario (1905a). On 3 June 1905, Pedley followed up with a letter (with a draft Government of Canada Order-in-Council for Treaty No. 9) to Laurier stating:

I deem it advisable in the absence of Mr. Oliver [newly appointed Superintendent General of Indian Affairs; Table 1] to bring to your attention the recent communication from the Province of Ontario and my memorandum thereon, immediately hereunder, with 
reference to the proposed new Treaty. It is desirable that the Treaty should be made as soon as possible and there is not much time to be lost if it is to be concluded this summer and fall.

$$
\text { (Pedley, 1905g:1) }
$$

The urgency in Pedley's letter is evident. The Dominion's Treaty No. 9 Commissioners were scheduled to leave Ottawa, Ontario, on 30 June 1905 (Scott et al., 1905; Long, 2010), so that the treaty expedition would be able to travel to and leave Dinorwic, Ontario, on 1 July 1905 (Pedley, 1905h). The Commissioners needed the treaty in hand, to be signed by the Indians of northern Ontario. Dinorwic was a small Canadian Pacific Railway station in northern Ontario (Scott, 1906; Dragland, 1994; Long, 2006).

Similarly, Pedley's letter to Matheson on 5 June 1905 had a sense of urgency:

Upon submission, the draft Order-in-Council as amended by your Government [of Ontario] has been accepted and a memorandum to His Excellency in Council [Government of Canada] has been prepared following the wording adopted in that document. I beg to request that similar action shall be taken by your Government [of Ontario] and a memorandum prepared for the Lieutenant-Governor in Council [Government of Ontario]. When the Orders-in-Council pass, copies may be exchanged. I have to request that you will at once consider the appointment of your representative on the [Treaty] Commission. It is probable that the party leave Biscotasing [Dinorwic was written over top] during the first week in July, and it is highly important that all preliminary arrangements should be made without delay.

(Pedley, 1905i:1)

On 9 June 1905, Canada's Order-in-Council \#1905-1065 (LAC, 1905a) was approved with respect to the terms of Treaty No. 9 as specified to gain Ontario's concurrence (McGee, 1905; Table S3). Thereafter, on 12 June 1905, Pedley (1905j) sent a letter to Matheson with a copy of a draft of the proposed Treaty No. 9 as per the terms of Orderin-Council \# 1905-1065 (LAC, 1905a) expressing his desire for an early reply and Ontario's approval. Pedley (1905k) also telegraphed Matheson on 15 June 1905 inquiring about the name of Ontario's Treaty No. 9 Commissioner, so that arrangement for the treaty making expedition could be finalized.

Pedley assumed that the negotiations with Ontario to gain concurrence for Treaty No. 9 were completed. Thus, Pedley's (1905h) correspondence with Matheson on 16 June 1905 contained near-to-final details of Treaty No. 9: his letter provided the itinerary for the Treaty No. 9 expedition (e.g., leaving Dinorwic, Ontario, 1 July 1905) and a telegram requested "wire approval of text of treaty which must be engrossed [on vellum]" (Pedley, 19051:1). Matheson's sameday telegraph reply to Pedley read, "Indian treaty matter has been referred to a Committee of Council cannot answer until next week" (Matheson, 1905b:1). At this point-in-time, Treaty No. 9 consisted of the terms agreed upon by both Canada and Ontario in Canada's Order-in-Council \#19051065 (LAC, 1905a; Table S3), but this would change.

\section{The Changing Form of Concurrence}

On 23 June 1905, Pedley (1905m:1) sent a letter to Matheson reiterating that the Treaty No. 9 field expedition "departure should take place from Dinorwic about the 1st July [1905]" so that Matheson could advise Ontario's Treaty No. 9 Commissioner of the departure date. The Treaty No. 9 Commission from Dinorwic would be travelling through rugged northern Ontario terrain by canoe (Chipman, 1905). To arrive at Dinorwic by 1 July 1905, the Treaty No. 9 Commissioners would have to leave their points of departure by approximately 30 June 1905. Thus, time was of the essence to get the Treaty No. 9 expedition started in 1905 or else an embarrassing request for allocation of Treaty No. 9 funds would have to be made by Indian Affairs to the Parliament of Canada for a third time.

In addition, 23 June 1905 was an important date for another reason. On this date, Treaty No. 9 was fundamentally changed in form, when Matheson (1905c; Table S4) telegraphed Pedley that an agreement would be forthcoming with respect to Treaty No. 9 under strong advisement of provincial counsel. The 23 June 1905 letter from Matheson to Pedley (Table S4) stated:

I enclose herewith draft of amended Order-in-Council and draft of agreement between the Province and the Dominion...As to the draft treaty with the Indians, I do not see any objections to it, except that it [Treaty No. 9] might be well to refer to the agreement between the Province and the Dominion in it.

(Matheson, 1905d:1-2)

Thus, the draft form of Treaty No. 9 as a single document evolved into a draft Treaty No. 9 package at the last minute, because Ontario wanted reference to the Agreement between themselves and Canada in the text of Treaty No. 9. Hence, the draft Agreement would become part of the Treaty No. 9 package due to the insistence of Ontario.

\section{What was in the Agreement?}

The draft Agreement between F. Oliver (Minister of the Interior and Superintendent General of Indian Affairs, Dominion of Canada) and F. Cochrane (Minster of Lands and Mines, Government of Ontario) gave a description of already agreed upon terms that were in the draft Treaty No. 9 document, based on terms of the Government of Canada Order-in-Council \#1905-1065 (LAC, 1905a). These agreed upon terms included the boundaries of Treaty No. 9, the payment of gratuities and annuities to Indians, the choice of location of reserves, and the appointment of a Treaty No. 9 Commissioner by Ontario (Table S4). In addition, new 

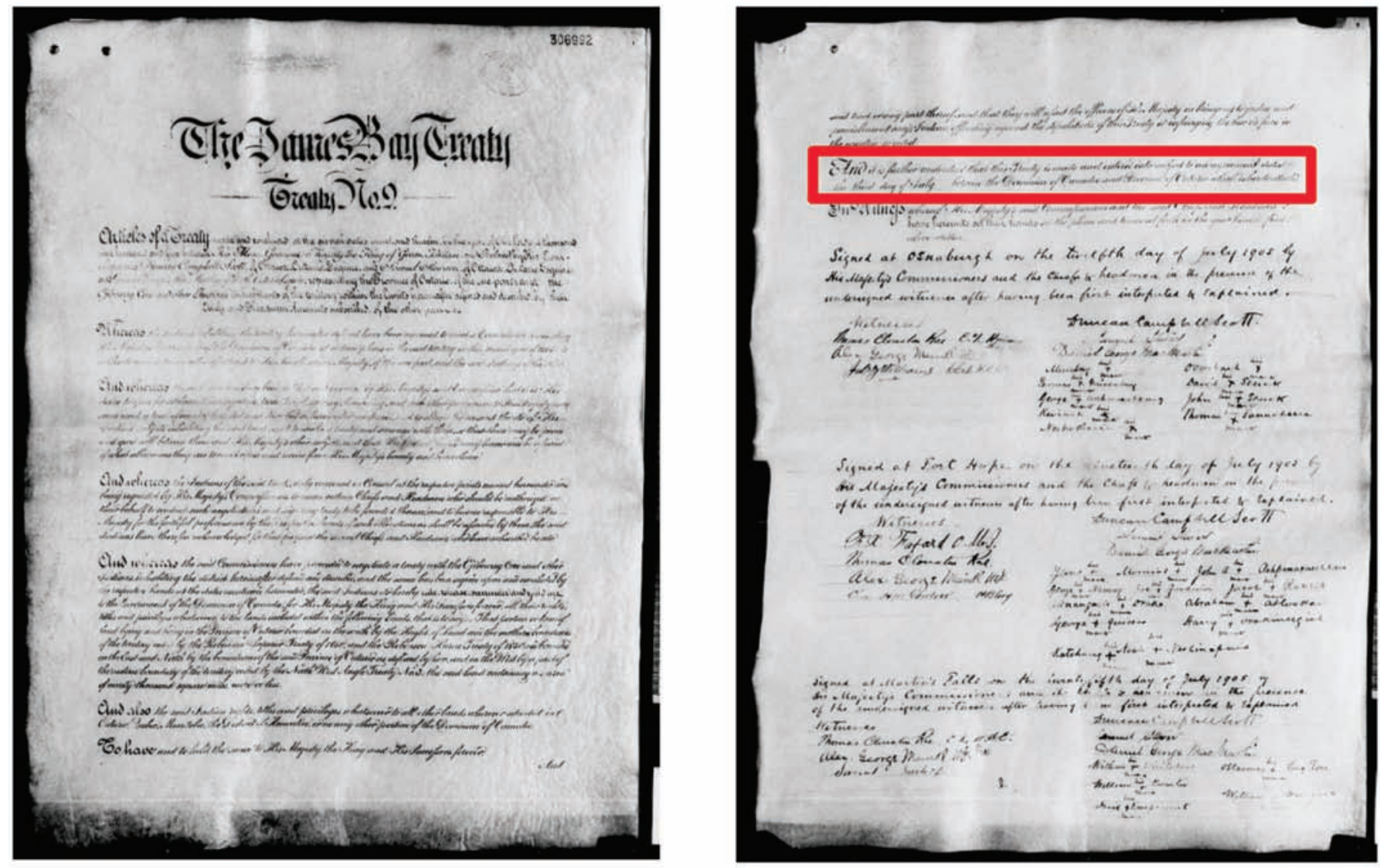

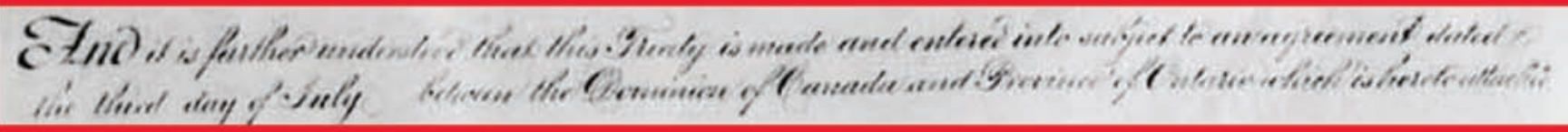

FIG. 3. Pages 1 and 3 of the Government of Canada's vellum copy of the James Bay Treaty-Treaty No. 9 document (Treaty No. 9, 1905). Note that the Agreement date has been backdated and identified as the "third day of July." Significantly, no year was added after the "the third day of July" because the original calligrapher did not leave enough space for this important detail. Also noteworthy is that the Agreement was supposed to be "hereto attached" to Treaty No. 9 to be a part of the Treaty No. 9 package presented to signatories, but it was not.

stipulations were in the Agreement that the Government of Ontario would not pay for the surveys necessary for locating Indian reserves, and Ontario would bear none of the costs associated with Treaty No. 9 expeditions (Table S4). Moreover, the clause, "And further, that no site suitable for the development of water power exceeding 500 horse power shall be included with the boundaries of any reserve" (Government of Ontario, 1905b:4) would now become part of Treaty No. 9 through the Agreement. This clause impacted where Indian reserves would be located and foreshadowed Ontario's development plan for the region. Although Pedley (1905n; Table S4) did not see any outstanding issues with the draft Agreement, on 24 June 1905 he sent a letter to Newcombe for his opinion of the draft Agreement.

The 26 June 1905 date was important for several reasons: Newcombe (1905b) returned the draft Agreement to Pedley, made some verbal changes, and approved the Agreement as revised; Pedley (1905o) then sent out a memorandum endorsing the Agreement (Table S4). As noted by Long (2010), timelines were tight for a 30 June 1905 departure of the Treaty No. 9 Commission, and Pedley would have likely agreed to most anything. Also, on 26 June 1905, S. Stewart, Assistant Secretary of Indian Affairs, sent a letter to the Undersecretary of State, Government of Canada, stating:

I beg to enclose herewith [a paper] copy of Treaty No. 9. Would you kindly cause this to be engrossed on parchment at as early a date as possible? You will observe that there are certain omissions [such as, the actual date the Agreement between the Province of Ontario and the Dominion of Canada was signed, because the Agreement had not yet been signed] for which blanks should be left to be afterwards filled in.

(Stewart, 1905a:1)

Once the text of Treaty No. 9 was engrossed on vellum, the written terms of the treaty were physically fixed on 

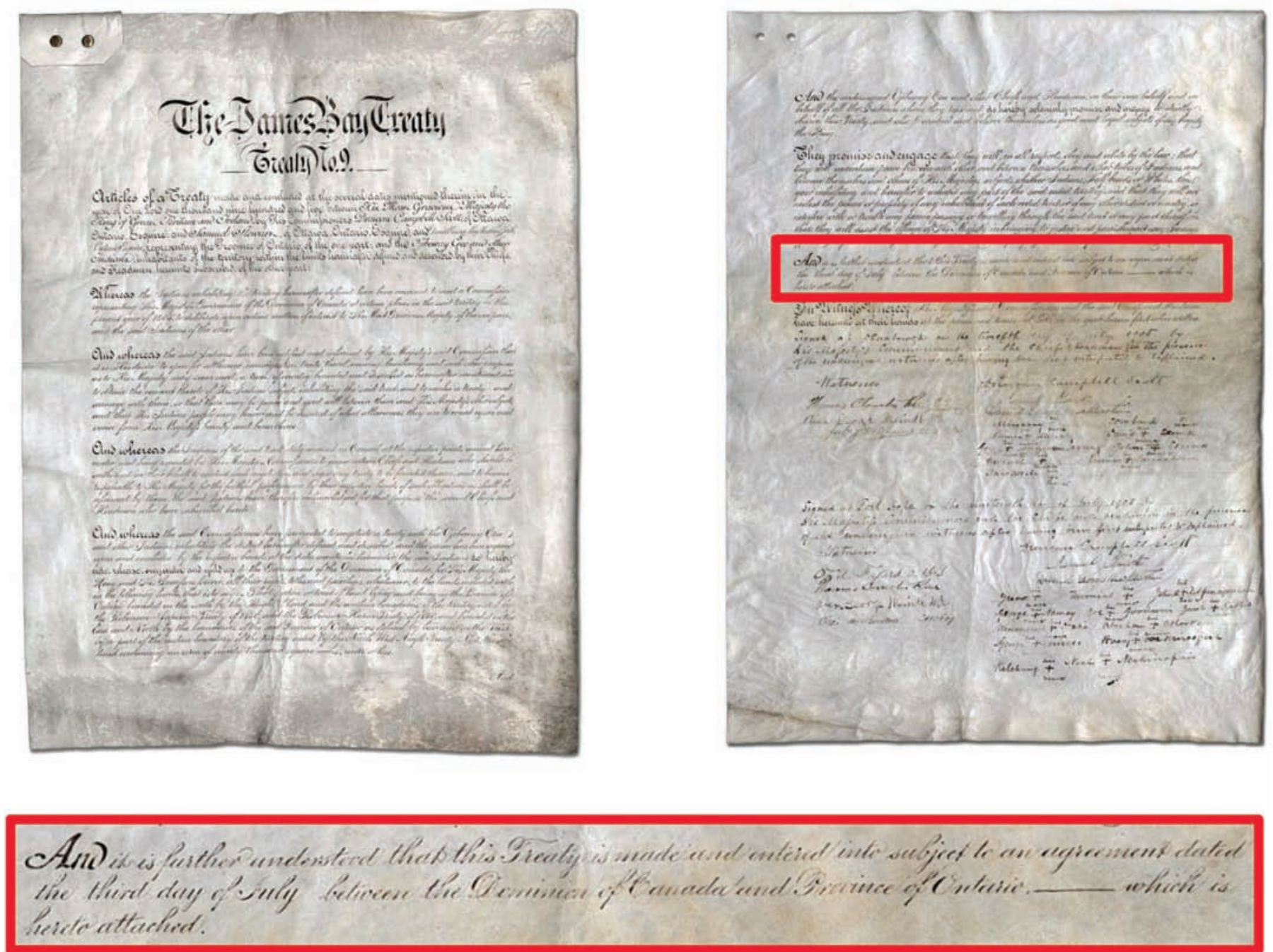

FIG. 4. Pages 1 and 3 of the Government of Ontario's vellum copy of the James Bay Treaty-Treaty No. 9 document (Treaty No. 9, 1905). Details as given in the Figure 3 caption.

the vellum (Tsuji and Tsuji, 2021). Two vellum copies of Treaty No. 9 were produced-one copy for Ontario and the other for Canada (Figs. 3 and 4). Both vellum copies were taken by the Treaty No. 9 Commission to be signed by the Indians, government officials, and witnesses in northern Ontario. The vellum copies of Treaty No. 9 could not be modified, which is why the blank spaces were necessary on the vellum (Stewart, 1905a) to later add the date of the Agreement to the Treaty No. 9 text (Tsuji and Tsuji, 2021; Figs. 3 and 4). The Agreement between Ontario and Canada when engrossed on vellum and then signed by government officials could then be added to complete the Treaty No. 9 package, and the Agreement date filled into the space left for it in the Treaty No. 9 vellum document (Tsuji and Tsuji, 2021).

\section{The Treaty No. 9 Expedition}

On 27 June 1905, Oliver made a submission to the Governor General in Council with respect to the Agreement (Oliver, 1905). However, as stated in a memorandum by
Scott, the Order-in-Council had not yet passed as of 29 June 1905:

When the Order-in-Council based on our Memo. of the 27th June passes, it will be necessary to have the Agreement itself engrossed [on vellum] by the Secretary of State and then signed. This will be afterwards attached to the treaty and form part of the original document.

(Scott, 1905b:1)

Thus, when the Dominion Treaty No. 9 Commissioners left Ottawa on 30 June 1905 for Dinorwic (Scott et al., 1905; Long, 2010), Canada's Order-in-Council with respect to the Agreement had not yet been passed. It then follows that the Agreement could not have been part of the Treaty No. 9 package that left with the Treaty No. 9 Commissioners in 1905, and the date of the Agreement could not have appeared in the Treaty No. 9 vellum document.

The Treaty No. 9 Commissioners (i.e., D.C. Scott and S. Stewart appointed by the Dominion and D.G. MacMartin 
appointed by Ontario) arrived in Dinorwic on 2 July 1905 (Scott et al., 1905). Subsequently, they began their northward expedition into the wilderness of northern Ontario by canoe on the morning of 3 July 1905 (Scott et al., 1905). At this point, correspondence with the Treaty No. 9 expedition could no longer take place because there was no form of rapid communication in the remote wilderness of northern Ontario (Babe, 1993; Tsuji and Tsuji, 2021).

Of importance, it was not until 3 July 1905 that Canada passed Order-in-Council \#1905-1262 (LAC, 1905b) related to the 27 June 1905 submission, about the Agreement between Canada and Ontario related to concurrence:

[The Minister of the Interior and the Superintendent General of Indian Affairs recommends] that the authority to so negotiate and to conclude any such treaty be subject to the passage of an Order of the LieutenantGovernor-in-Council expressing the concurrence of the Government of Ontario and its consent to the conclusion of a treaty upon the above terms. The Committee submit the same for approval.

(LAC, 1905b:6)

The date of the Agreement was left blank in Canada's Order-in-Council \#1905-1262, and an agreement between the Government of Ontario and the Dominion of Canada dated 7 July 1902 (hereafter referred to as the 1902 Agreement) was included with the Order-in-Council \#1905-1262 (LAC, 1905b) material. Specifically, the 1902 Agreement was included because the Agreement stipulated:

That subject to the provisions contained in the herein before recited agreement of 16th April, 1894, and also the agreement made on 7th July, 1902, by Counsel on behalf of the Governments of the Dominion and Ontario, intervening parties, upon the appeal to the Judicial Committee of the Privy Council in the suit of the Ontario Mining Company v. Seybold et al. (Ont. S.P., 1904, No. 93) a copy whereof is hereto attached.

(LAC, 1905b:9; see also Table S4)

Thus, over a very short period of time, Treaty No. 9 changed from a single document (12 June 1905; Pedley, 1905k; Table S3) into a treaty package that also contained the Agreement (23 June 1905; Matheson, 1905d; Table S3). In addition, the 1902 Agreement became part of the Treaty No. 9 package because of a stipulation in the Agreement (Government of Ontario, 1905b). As detailed by Oliver (1905:3) in Canada's Order-in-Council \#1905-1262 (LAC, 1905b), the next step was to have Ontario pass an "Order of the Lieutenant-Governor-in-Council expressing the concurrence."

\section{Backdating the Agreement}

On 14 July 1905, Pedley sent a letter to Matheson informing him, that an [Order-in-Council]...has been passed, dated the 3rd instant, authorizing negotiations for the cession of territory in what is known as Treaty No. 9, on the terms and conditions set forth in the draft agreement, which will be engrossed [on vellum] in due time and submitted for signature.

(Pedley, 1905p:1)

However, it was not until 16 October 1905 that Pedley (1905q) sent in duplicate the Agreement engrossed on vellum to F. Cochrane, Minister of Lands and Mines, Ontario (although Cochrane was incorrectly identified as the Minister of Mines and Works by Pedley in his letter):

I beg to send you under separate registered cover the agreement in duplicate between the Government of the Dominion of Canada...Frank Oliver...and yourself... This agreement forms a part of Treaty No. 9 which, when properly executed, will be attached to the Treaty one copy of which will be transmitted in due course to your Government.

(Pedley, 1905q:1)

Pedley's (1905q) correspondence confirms our earlier assertion that the Agreement was not part of the Treaty No. 9 package that left with the 1905 treaty expedition. The version of Treaty No. 9 signed during the 1905 Treaty No. 9 expedition was incomplete, because the Agreement had not yet been executed and brought into force. Furthermore, the Agreement had to be "hereto attached" as specified in the Treaty No. 9 text (p. 3; Figs. 3 and 4) and was not.

It was not until 17 November 1905 that Matheson sent a letter to Pedley concerning the Agreement:

I beg to enclose herewith the agreement in duplicate... which has been executed by the Hon. Frank Cochrane [Minister of Lands and Mines] and seal attached. Would you kindly have your departmental or other seal affixed to Hon. Mr. Oliver's signature, and the dates filled in, and return one copy with the Treaty attached. I think it would be proper in this case to make the date of the agreement some day previous to the date in the Treaty.

(Matheson, 1905e:1)

Yet Matheson, through an oversight, had not enclosed the executed Agreement with F. Cochrane's signature and seal (Cochrane, 1905; Pedley, 1905r). Nonetheless, by 1 December 1905 Pedley indicated that he had received the executed Agreement from Ontario, and Canada had executed the Agreement on their part:

The copy of the agreement...was duly received...The date has been filled in as of the 3rd of July [1905] and the official seal has been affixed to Hon. Mr. Oliver's signature.

(Pedley, 1905s:1; see also Table S4) 
Although there should exist two copies of the Agreement-one in the possession of Ontario and the other in the possession of Canada - we have only been able to locate Canada's copy. There is no vellum copy of the Agreement in the Archives of Ontario. We made an inquiry on 25 September 2019 about the Agreement, pointing out that the agreement that Archives of Ontario labelled as page 7 of Treaty No. 9 was in fact not the Agreement, but the 1902 Agreement. The Archives of Ontario archivist was helpful, but could only direct us to the vellum copy of the Agreement held by Library and Archives Canada, which is Canada's copy that we already possessed as a digital file.

In Canada's vellum copy of the Agreement, while Oliver's signature and seal are evident on the last page, only Cochrane's signature is discernable (Fig. 5); Ontario's seal appears to be missing contrary to Matheson's (1905e) assertion. It should also be noted that the backdated execution date occupies the entirety of the second line of the Agreement ("Third day of July in the year of Our Lord 1905"; Agreement Between the Dominion of Canada and the Province of Ontario, 1905:1; Fig. 5). Leaving an entire line blank in the Agreement allowed for the addition of the entire date of execution including year.

By contrast, not enough blank space was set aside by the calligraphers to accommodate the full-backdated execution date of the Agreement, with respect to the vellum copies of Treaty No. 9. Only enough space was left to backdate the Agreement to the "third day of July" in both copies of Treaty No. 9; there was not enough space to accommodate the year 1905 (Figs. 3 and 4). In both vellum copies of Treaty No. 9, spacing inconsistencies are evident on the line where "third day of July" appears (Figs. 3 and 4), which is probably why the 1902 Agreement appears as page 7 of Treaty No. 9 on the Archives of Ontario website. Without the year of the Agreement appearing in Treaty No. 9's text, there was confusion over the year of the referred to agreement; there was also no mention of who signed the agreement on behalf of Canada and Ontario. Thus, it is understandable how Archives of Ontario included the 1902 Agreement as page 7 of Treaty No. 9, taking into account that Ontario's vellum copy of the Agreement appears to be misplaced, and the 1902 Agreement was part of the Treaty No. 9 package. Adding further, the 1902 Agreement was between the Dominion and Ontario and was signed in July, but the 1902 Agreement was dated the 7th of July, not the 3rd of July. However, one has to examine the 1902 Agreement very carefully to distinguish the difference in dates (Fig. 5).

Interestingly, in the typeset printed copy of the James Bay Treaty-Treaty No. 9 with manuscript corrections on page 3 , line 14 , following "an agreement dated the third day of July," "nineteen hundred and five" has been crossed out, supposedly because the year does not appear in the original vellum Treaty No. 9 document (Treaty No. 9, undated). Nevertheless, in the official Government of Canada 1907 printed paper version of the James Bay Treaty-Treaty No. 9, the original typeset version of line 14 appears, "an agreement dated the third day of July, nineteen hundred and five" (Treaty No. 9, 1907:18, line 14). Subsequently published official Government of Canada editions contain the same wording (e.g., Treaty No. 9, 1964:21, lines 22-23), perpetuating an untruth.

In addition, backdating the Agreement to 3 July 1905 was not a wise decision in deception. Although 3 July 1905 was prior to the date of 12 July 1905, when Treaty No. 9 was first signed at Osnaburgh (Treaty No. 9, 1905), the Treaty No. 9 Commission had already started their northward journey by canoe on 3 July 1905 (Scott et al., 1905; Tsuji and Tsuji, 2021) from Dinorwic to Lac Seul (Long, 2010). Since there was no form of rapid communication at this time in the wilderness of northern Ontario, correspondence with the Treaty No. 9 expedition was no longer possible (Babe, 1993; Tsuji and Tsuji, 2021). Even if the Agreement had been fully executed on 3 July 1905, there was no quick way to get the vellum copies of the Agreement to the Commission while in the field.

\section{What Constituted the James Bay Treaty-Treaty No. 9?}

As asserted by Long (1989:41), "Unfortunately, there is simply no consensus about what Treaty Nine represents." Long (2006) contends that there were actually two treaties: one was the official written version of Treaty No. 9, while the other version was the one orally explained to the First Nations people (i.e., oral promises) and substantiated by First Nations' oral history, as well as preserved in the Treaty No. 9 Commissioner's own writings (Long, 1993, 2011; Armstrong, 2008; Louttit, 2010). Acknowledging that there is substantial evidence for an oral-promises version of Treaty No. 9, we have limited our discussion to only the written version of Treaty No. 9. In brief, we have shown that Treaty No. 9 quickly evolved from a single document (12 June 1905; Pedley, 1905k; Table S3) into a package with two other distinct parts: the Agreement (23 June 1905; Matheson, 1905d; Table S3) and the 1902 Agreement (Government of Ontario, 1905b). On 18 December 1905, J. McLean, Secretary of Indian Affairs sent a letter to J. Pope, Under Secretary of State, Canada to request that:

you will be good enough to have two copies engrossed of the attached Agreement of the 7th July, 1902, on parchment...being the same size as the Treaty [No. 9] recently engrossed in your Department.

(McLean, 1905:1)

Once the vellum copies of the 1902 Agreement were ready in February 1906, the two official Treaty No. 9 vellum packages were completed. So theoretically, the 1906 Treaty No. 9 expedition, which travelled to locations where the 1905 expedition did not fulfill treaty activities (Scott et al., 1906), could have taken the completed Treaty No. 9 vellum package, but we do not see evidence for this conjecture. Indeed, the letter dated 1 November 1906 from Matheson to S. Stewart, Acting Deputy Superintendent 

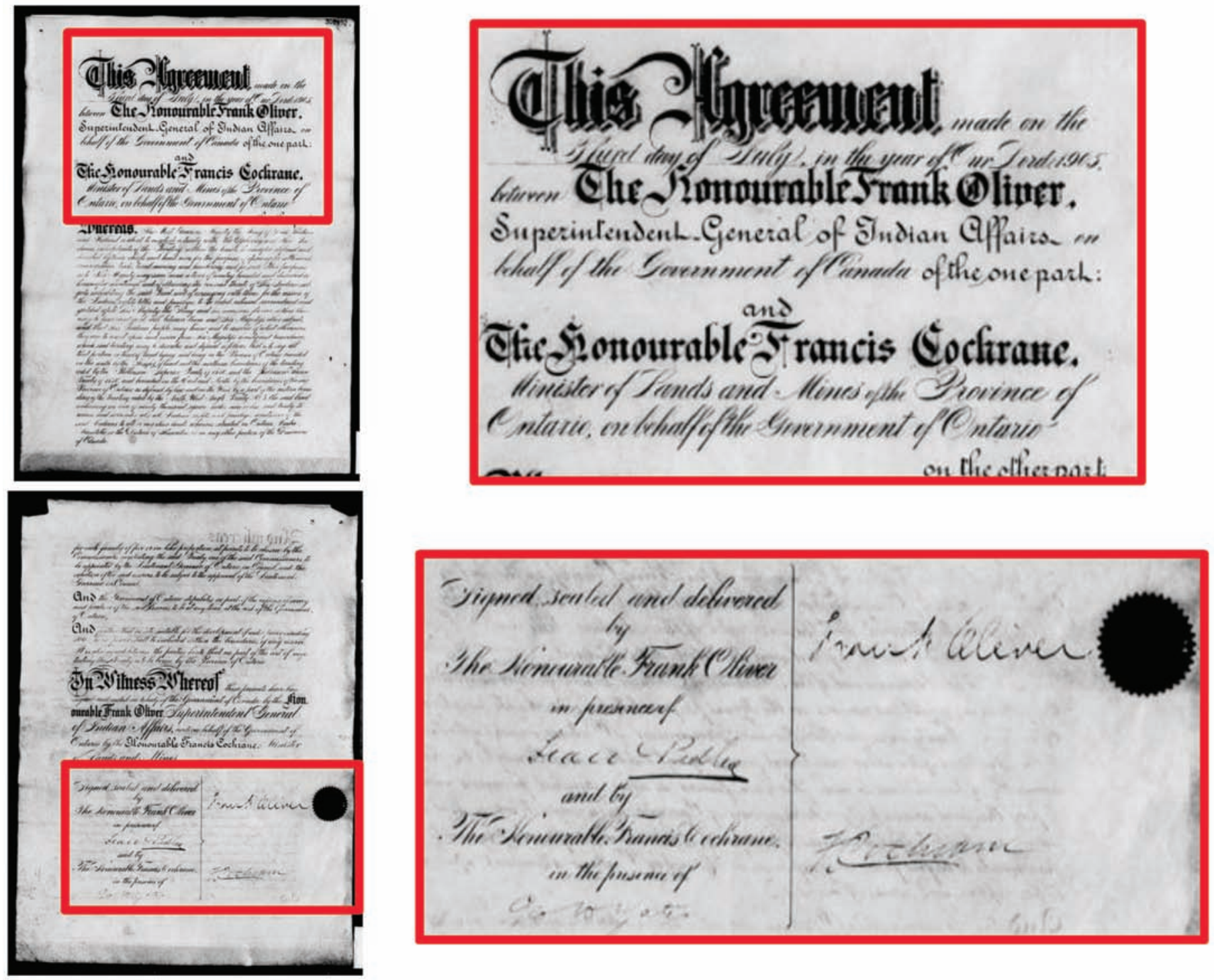

FIG. 5. Pages 1 and 3 of the Government of Canada's vellum copy of the Agreement dated July 3, 1905 (Agreement Between the Dominion of Canada and the Province of Ontario, 1905). Note that the full backdate of 3 July 1905 was included in the Agreement, and the relatively pristine condition of the Agreement compared to the vellum copies of the Treaty No. 9 document.

General of Indian Affairs, suggests otherwise and confirms that at least Ontario's vellum copy of the Agreement never left the provincial office for the field:

I am in receipt of yours of the 26th October enclosing a completed copy of the James Bay Treaty No. 9 which will be attached to the copy of the Agreement between the Dominion Government and the Province of Ontario.

(Matheson, 1906:1)

If the completed vellum Treaty No. 9 package with the Agreement and 1902 Agreement travelled with the Commissioners in 1906, creases would be visible on the vellum of the Agreement and the 1902 Agreement (Figs. 5 and 6), similar to the creases clearly visible on the vellum copies of Treaty No. 9 (Figs. 3 and 4). Worn creases from folding and travelling by canoe in northern Ontario are not visible on the vellum versions of the Agreement and the 1902 Agreement. If the Treaty No. 9 package was the incomplete one used in 1905-Scott's (1906) assertion appears to indicate this scenario-it follows that if there was no Agreement attached, there was nothing to explain on his part. This line of reasoning is explored more fully below.

Thus, in reality, there were no negotiations between the Treaty No. 9 Commission and the Indians (Morrison, 1986, 1988; Long, 1989, 2010; Dragland, 1994), as the terms of Treaty No. 9 were immutable. In the Treaty No. 9 Commissioner's own words:

under the provisions of clause 6 [the Statute of Canada, 54-55 Vic., chapter V]...the terms of the treaty [No. 9] were fixed by the governments of the Dominion and Ontario; the commissioners were empowered to offer 

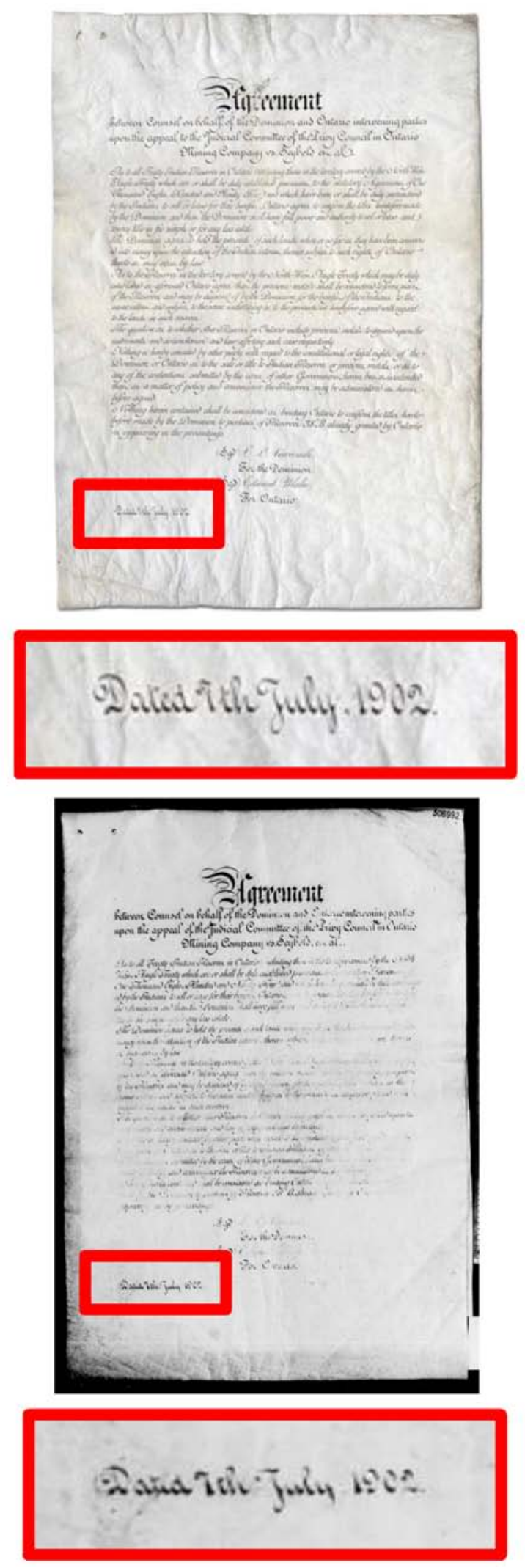

FIG. 6. The Government of Ontario's vellum copy of the 1902 Agreement is in the top corner, and the Government of Canada's vellum copy of the 1902 Agreement is in the bottom corner (Agreement Between the Dominion of Canada and the Province of Ontario, 1902). Note the relatively pristine condition of the Agreements compared to the vellum copies of the Treaty No. 9 document. certain conditions, but were not allowed to alter or add to them in the event of their not being acceptable to the Indians.

(Scott et al., 1905:1-2).

Nevertheless, the complete Treaty No. 9 vellum package should have been present at the time of "negotiations" and signing of said treaty by Indians, in the context of legality. Further, the Treaty No. 9 document stipulated that:

His Majesty agrees that each Chief, after signing the treaty, shall receive a suitable flag and a copy of this treaty to be for the use of his Band.

(Treaty No. 9, 1905:2)

Of course, no copies of the Treaty No. 9 document or package were distributed in 1905, because the Agreement was not executed before the Treaty No. 9 Commission left Dinorwic. It was not until the summer of 1906 that copies of Treaty No.9 were distributed to the Indian leaders (Long, 2006); but the version of Treaty No. 9 distributed is unclear.

\section{Treaty No. 9: Commission Articles}

Scott (1906:578), one of the Dominion's Treaty No. 9 Commissioners, clearly states that the First Nations people signing Treaty No. 9 knew nothing of the Agreement:

They [Indians] were to make certain promises and we [Government of Canada] were to make certain promises, but our purpose and our reasons were alike unknowable. What could they grasp of the pronouncement on the Indian tenure which had been delivered by the law lords of the Crown, what of the elaborate negotiations between a dominion [Government of Canada] and a province [Government of Ontario] which had made the treaty possible, what of the sense of traditional policy which brooded over the whole? Nothing. So there was no basis for argument.

In reference to Scott's (1906) article in Scribner's Magazine, other researchers (e.g., Long, 2010; Armstrong, 2013) reached the same conclusion. Macklem (1997:127) added further that: "There is no record of any explanation offered of the clause prohibiting the establishment of reserves near sites suitable for hydroelectric development or that the provincial commissioner explained the reasons for the insertion of this clause to Aboriginal signatories." Likewise, Pelham Edgar's series of articles (1906a, b, 1907a-f), based on his time as the Treaty No. 9 secretary for the 1906 expedition, made no mention of the Agreement being explained to the Indigenous signatories or that the choice of reserve locations was restricted by hydroelectric potential. Long (2010) also reported no mention of the Agreement in reference to the Pelham articles. 


\section{Treaty No. 9: Commission Diaries}

We found no definitive evidence that the Agreement or waterpower were ever discussed by the Treaty No. 9 Commissioners with the First Nations' signatories in reference to the Treaty No. 9-Commission diaries (also referred to as journals) (MacMartin, 1905; Scott, 1905c; Stewart, 1905b, 1906; Edgar, 1906c). MacMartin (2015:206) also reported with respect to D.G. MacMartin's (1905) diary that "No indication of the Ontario-Canada agreements pertaining to Treaty 9 having been mentioned at all or explained." In more extensive studies of the whole set of diaries, Armstrong $(2000,2013)$ reported that the intergovernmental Agreement and waterpower were not discussed by the Commissioners with the Indigenous signatories. In an extended study by Armstrong (2008) that also included First Nations' oral history, no evidence was found that the Agreement was mentioned during Treaty No. 9 negotiations. Likewise, Long (2010:357) noted that "There is no mention whatsoever of this [1905] agreement...in [all of] the commissioners' journals." However, in just a year, the late J. Long (2011:187) softened his stance: "Mention of a prior agreement signed by the two governments? Maybe (Stewart [diary]), but probably not (MacMartin [diary], Scott [diary])." Perhaps Long (2011) reevaluated the diaries and found that there was some ambiguity with the following passage contained in the Stewart (1905b:38-39) diary, as we did:

The Indians asked several questions as to whether they would be compelled to live on the reserve to be set apart for them, and as to whether their fishing and hunting privileges would be curtailed. On being informed that they could continue to live as they and their forefathers had done, and that they could make use of any lands not disposed of by the Govt they appeared to be satisfied, but asked to be given to the following day to enable them to talk over the terms of the agreement with their members of the band, which was at once agreed to.

Even though it appears that the Commissioners did not inform the First Nations' people of the Agreement and waterpower-reserve stipulation, there was still hesitancy on the part of the First Nations' people with respect to signing Treaty No. 9. For example, at Fort Hope (Eabametoong) Stewart (1905b:56-57) wrote:

The Indians present, they being very much concerned as to what they were expected to give up for the benefits they were to receive. It required some time to convince them that there was not something behind the terms of the agreement set forth in the treaty, for as Moonias, one of the principal men of the band stated, they were not giving up very much for what they were to receive [gratuity and annuity money], and it had never been his experience to receive something for nothing. Father Fafard, fully explained to the Inds the nature of the treaty and the reasons for asking them to surrender the title to their unused land...The Indians then signified their willingness to sign the treaty, which was accordingly done.

Meanwhile, MacMartin (1905:34-35) reported that:

Moonias, said, I should like to consult with my aunts and cousins. If I buy as small an article as a needle I have to pay for same, you come here offering money we have not asked for I do not understand, and should like to have it explained. After an explanation, he along with the others signified his assent and the Treaty was signed.

Even the official Commissioner's report stated:

Moonias, one of the most influential chiefs, asked a number of questions. He said that ever since he was able to earn anything, and that was from the time he was very young, he had never been given something for nothing; that he always had to pay for everything that he got, even if it was only a paper of pins. "Now," he said "you gentlemen come to us from the King offering to give us benefits for which we can make no return. How is this?" Father Fafard thereupon explained to him the nature of the treaty, and that by it the Indians were giving their faith and allegiance to the King, and for giving up their title to a large area of land of which they could make no use, they received benefits that served to balance anything that they were giving.

(Scott et al., 1905:paragraph 27)

Clearly, the First Nations' representatives were suspicious of the treaty terms because they would be giving up nothing while receiving "benefits"; obviously, the First Nation representatives were not told of the Agreement. As noted by Armstrong (2008:2), from a First Nations' perspective they would be relinquishing nothing because there were no "unused lands" (see Table S1) in their homelands.

Once the treaty was signed, reserves were chosen according to the terms of Treaty No. 9 (1905:2):

And His Majesty the King hereby agrees and undertakes to lay aside reserves for each band, the same not to exceed in all one square mile for each family of five, or in that proportion for larger and smaller families; and the location of the said reserves having been arranged between His Majesty's commissioners and the chiefs and headmen, as described in the schedule of reserves hereto attached, the boundaries thereof to be hereafter surveyed and defined, the said reserves when confirmed shall be held and administered by His Majesty for the benefit of the Indians free of all claims, liens, or trusts by Ontario. 
In the Treaty No. 9 Commissioners' official report, Scott et al. (1905:11) contended that "[f]or the most part the reserves were selected by the commissioners after conference with the Indians... No valuable water-powers are included within the [reserve] allotments."

It should be emphasized that reserve-size allocations were guesstimates because the size of the reserve was based on the number of people in the band in question. There were no reliable census numbers for the First Nations people in the Treaty No. 9 region, and many were not at the Hudson Bay post for Treaty deliberations because of the late start to the treaty expedition (Tsuji and Tsuji, 2021). Further, reserve locations were only crudely described in the Schedule of Reserves and in general non-specific because there was no surveyor with the Treaty No. 9 Commission.

As noted by Morrison (1986), very little was described in the official Treaty No. 9 Commissioners' report (Scott et al., 1905) on how the reserves were selected. Although Calverley (2006:47) contends that "[t]here is no indication in any of the available treaty documents that either the treaty commissioners or HBC [Hudsons Bay Company] employees coerced any bands into choosing their reserve location," we present another viewpoint. In MacMartin's (1905:56-57) diary, he describes a contentious reserve selection at Marten Falls:

Chief White head then delivered an oration, in wh[ich] he said, pointing up and down the river that they were being cornered by not being allowed both banks of the River...When it was explained to them that they could hunt and fish as of old and they were not restricted as to territory, the Reserve, merely being a home for them where in which no white man could interfere, or trespass upon, that the land was theirs for ever; they gladly accepted the situation, and said they would settle the reserve question later on...the chief and his councilors came to our quarters saying that they wanted both banks for 50 miles down river as a hunting reserve. Again it was put forcibly before them, that it was a home for them that was being provided \& not a hunting preserve and that they could hunt wherever they pleased. They signified their assent and the following land was allotted.

MacMartin (1905:39-40) also mentioned how the Chief and Councilors of Fort Hope (Eabametoong):

had after consultation decided upon the land they desired to have as a reservation asking for a water frontage of 100 miles. On being told that it was impossible to grant a tract of land of the dimensions asked for... the chief then said he was satisfied and after some discussion we proposed that the following land should be granted as their Reservation.

Evidently, Chiefs and Councilors were strongly discouraged from choosing reserves with large areas of water frontage, but we could find no mention of waterpower reference in the diaries, except in the Stewart (1905b:120) journal:

One could not [but] be struck with the fact on this river [Abitibi], that however it may be used in future to provide water power, it can never be made navigable, as it has so many rapids and waterfalls throughout its whole length.

The only account of waterpower potential influencing reserve selection with respect to the Treaty No. 9 Commissioners was found in Morrison (1986:46):

Robert Laurence [an apprentice clerk at the time at the Mattagami Hudson Bay Company Post] later remembered [during a 1974 interview] that the Mattagami Band had originally wanted a site east of the post that was good deer-hunting country, but James Miller, the local [Hudson's Bay] Company manager, persuaded them that Kenogamissi Falls down river was a better choice because of its power potential. Since the commissioners "wouldn't allow that," he added, Mr. Miller "got them the only place—where [sic] they eventually got" because "he knew there was some good pine there."

\section{Reserve-Survey Correspondence}

As shown above, reserve selection was a contentious issue during Treaty No. 9 deliberations. Afterwards, reserve locations remained an issue even prior to the reserves being surveyed. For example, Manore (1999) gave an in-depth account about a "clerical error"; the discrepancy was between what was agreed to at Mattagami with respect to reserve location and what was written in the Treaty 9 report. Although Ontario agreed to "change" the reserve location, it was only after securing timber rights with respect to the reserve lands (Manore, 1999).

When W. Galbraith, Ontario \& Dominion Land Surveyor, entered the field to demarcate Treaty No. 9 reserves, reserve-location issues did not subside. For Osnaburgh reserves, Galbraith (1909:1) reported:

I was unable to complete the survey of these reserves as the Indians are not satisfied with the location according to the Treaty - they would not assist me to make the survey unless I made radical changes in the location of the Reserves...I will be able to send you a plan showing what the Indians now desire as Reserves.

In addition, at Fort Hope, First Nations' leadership asked Galbraith (1910a:4) "to have the reserve limits moved." Thus, Galbraith did not complete his survey of reserves at Osnaburgh or Fort Hope (Galbraith, 1910a). Shortly after Galbraith (1910b) submitted his report, he mailed in 
his resignation blaming the wet working conditions in the muskeg leading to "rheumatic trouble."

J. Dobie (1911), Ontario \& Dominion Land Surveyor, was Galbraith's replacement. Although Galbraith's instructions from Indian Affairs were brief and non-specific for surveying Treaty No. 9 reserves, Dobie's instructions from Indians Affairs (McLean, 1911:1-2) were relatively extensive and specific:

I have to say for your general guidance that the location of all reserves provided for in the Treaty [No. 9] on the South or Ontario side of the [Albany] River are not to be changed. You should adhere to them as closely as possible. On the north side of the river, that is to say in Dominion lands, you may change the locations, but only when urgently requested to do so by the Indians.

You will please be careful to exclude by survey from all reserves where water-powers occur on a main river, a tract of about eighty acres. These tracts should be regularly posted. You will please use your own judgement as to the depth and length that may be required to utilize the water power.

In this connection [it] is to be noted that allowances for roads for access to the said water-powers will be required...be careful to let the Indians know that the Crown reserves the right to lay out roads for the public use across their reserves when they become necessary.

Following these specific instructions, Dobie (1912:6) reported:

A valuable water power exists at the northern outlet of the Albany River, and an area sufficient for the development of this power was surveyed out, and the Indians were informed that this water power reservation was not to be included in their reserve.

In overview, some First Nations groups were suspicious of the terms of Treaty No. 9 because they had "never been given something for nothing" (Scott et al., 1905). In keeping with this line of reasoning, we found no definitive written or oral history evidence that the Treaty No. 9 Commissioners ever mentioned the Agreement (or waterpower stipulation) to the First Nations' signatories prior to them signing Treaty No. 9. Afterwards when the First Nations' Treaty No. 9 signatories were choosing reserves, certain shoreline locations were not allowed. Indeed, at least at one site showing waterpower potential, it was reported, "the commissioners 'wouldn't allow that"” (Morrison, 1986:46). The last check for excluding areas with waterpower potential was during the actual surveying of the reserves. The instructions to Dobie, the surveyor for Indian Affairs were quite clear to exclude sites of waterpower potential from Treaty No. 9 reserves and make "allowances for roads for access to the said water-powers" (McLean, 1911:2).

\section{CONCLUSIONS}

Clearly, Treaty No. 9 was severely flawed. The lack of oversight by the people who drafted Treaty No. 9 has been documented in the Ontario Court (Bernstein, 1978) and in the work of Treaty No. 9 historians (e.g., Long, 2010; Tsuji et al., 2016; Tsuji and Tsuji, 2021). Long (2010) suggests that Treaty No. 9 may have been the first of the numbered treaties that lacked the oversight of the Colonial Office in Great Britain. Moreover, the last-minute negotiations with respect to Treaty No. 9-especially Ontario's demands for the Agreement between the Dominion of Canada and the Province of Ontario to gain their concurrence with respect to Treaty No. 9-led to an incomplete Treaty No. 9 package lacking the Agreement being presented to and signed by the Indians in 1905 . The evidence also suggests that this scenario most likely occurred in 1906. Additionally, when the date of the Agreement was added to the vellum copies of Treaty No. 9 and the Agreement in the blank spaces left for this purpose, the date of the Agreement was backdated to the "third day of July" (Figs. 3,4 , and 5). This act of deception was in order "to make the date of the agreement some day previous to the date in the Treaty" (Matheson, 1905e:1). However, the "third day of July" was not a wise choice for the Agreement date because the Treaty No. 9 Commission was already travelling by canoe into the wilderness of northern Ontario, and there was no way that the Agreement could have been part of Treaty No. 9 that left Ottawa on 30 June 1905, as we have shown. Therefore, the common law legality of Treaty No. 9 must be questioned. Also questionable is the legality of backdating the Agreement. What is not questionable is that the representatives of Canada and Ontario tried to deceive whoever would read Treaty No. 9 into believing that the Agreement was executed prior to the Indians signing Treaty No. 9 in 1905, even though the government officials left a paper trail that could be followed. Without the Agreement being first executed and put into force and "hereto attached" as specified in the Treaty No. 9 document that left Ottawa in 1905, consideration of the terms of the Agreement by the Indian signatories of the treaty could not have occurred.

One term in the Agreement that would have been of particular importance to the Indian signatories of Treaty No. 9 was the one stipulating that "no site suitable for the development of water-power exceeding 500 horse-power shall be included within the boundaries of any reserve" (Government of Ontario, 1905b:3). It should be emphasized that hydroelectric power development was not mentioned anywhere else in the Treaty No. 9 package except in the Agreement. Would the Indian signatories have signed Treaty No. 9 knowing the hydroelectric stipulation was in the Agreement and part of the Treaty No. 9 package? This question can never be definitively answered; however, it should be emphasized that some First Nations' leaders were already suspicious of the terms of Treaty No. 9 without even knowing about the Agreement and the waterpowerreserve stipulation. Nonetheless, the important fact is 
that First Nations leaders were not relayed the terms of the Agreement or, more importantly, the existence of the Agreement, so an informed decision on whether to sign the treaty could not have been made.

Historically, by the $1900 \mathrm{~s}$, hydroelectric-power generation was gaining importance in Ontario and fueling economic prosperity in the province (Titley, 1986). To the point, in the same year that Treaty No. 9's field expedition was completed in 1906, the Hydro-Electric Power Commission of Ontario was formed as a publicly funded and owned utility company of the Government of Ontario (Armstrong, 2000; Macfarlane and Kitay, 2016; Macfarlane and Watson, 2018). This crown corporation would later be known as Ontario Hydro after 1974 (Sholdice, 2019). Obviously, the importance of the Treaty No. 9 region for hydroelectric power generation and associated resource development was known prior to the Province of Ontario's demand for the Agreement (Manore, 1999; Armstrong, 2000; Mcfarlane and Kitay, 2016).

Indeed, the Treaty No. 9 Commissioners made sure that no valuable sites of potential water-power generation were included in the reserve allotments (Scott et al., 1905), and the second reserve surveyor was instructed by Indian Affairs to also take into account land that would be required for road access to potential waterpower sites (McLean, 1911). Surveyor J. Dobie (1912) did as he was instructed to do by Indian Affairs. Thus, it was not surprising when hydroelectric development began in the southern region of Treaty No. 9 (e.g., Moose and Albany River basins) in the early part of the 20th century without consultation with the First Nations (Armstrong, 2000; Long, 2010; Macfarlane and Kitay, 2016). The consequences of hydroelectric development in the Treaty No. 9 region have been severe (e.g., flooding of cultural sites, relocation of communities, and negative impacts on subsistence activities; Armstrong, 2000; Long, 2010; Macfarlane and Kitay, 2016). In this vein, as noted by Armstrong (2013:37): "Remarkably little was recorded by the [Treaty No. 9] Commissioners about what was said during the making of the Treaty about what might occur on the land in the future."

In closing, we have presented evidence that all land south of the Albany River ceded in Treaty No. 9 should be called into question from a common law perspective, unless documentation can be presented indicating that the complete Treaty No. 9 package was presented to the 1905 and 1906 Indian signatories; the existing evidence as we have shown indicates otherwise. The Treaty No. 9 package approved by the Dominion on 12 January 1907 (Orderin-Council \#1906-2499; LAC, 1907) and Ontario on 13 February 1907 (Capreol, 1907) was the complete Treaty No. 9 package. By contrast, it was the incomplete Treaty No. 9 package that was presented to and signed by the Indian leaders in 1905 and most likely 1906. Lastly, it is ironic that Ontario insisted on the Agreement so very late in the Treaty No. 9 deliberations in order to avoid future litigation (Matheson, 1905d). If Ontario had not insisted on the Agreement, there would not be the question of approximately 90000 square miles (or 233099 km²; Long, 2010) of unceded land from a common law perspective, south of the Albany River in northern and subarctic Ontario. The Agreement, rather than preventing litigation, will be the root cause of it. In the end, the courts will have to decide the legality of Treaty No. 9 from a common law perspective. Alternatively, a new process has been initiated by the Government of Canada:

It will consist of a new distinctions-based Policy on the Recognition and Implementation of Indigenous Rights to replace the Comprehensive Land Claims and Inherent Right Policies...The policy will facilitate the implementation and exercise of Indigenous rights, which includes building upon and strengthening Canada's approach to implementing existing and new treaties and agreements ...We have heard that Canada's current policy framework to support the recognition and implementation of Indigenous rights is flawed, and that past insistence on "cede, release and surrender" provisions in treaties and agreements is inappropriate and outdated. We need to address issues created by the Comprehensive Land Claims and Inherent Right Policies, such as the imposition of strict federal mandates that do not take the distinctions between Indigenous groups into account, and inappropriately rigid approaches to certainty that impede the renewal of relationships... [need to] entrench co-development as the basic standard for federal engagement with Indigenous peoples to advance the implementation of their rights.

(CIRNAC, 2018)

Currently, more than 390 Indigenous communities have been involved in $\sim 80$ Recognition of Indigenous Rights and Self-Determination Discussion Tables with the Government of Canada (CIRNAC, 2019). Perhaps this process will be the way forward for the Treaty No. 9 First Nations.

\section{ACKNOWLEDGEMENTS}

We thank the Social Sciences and Humanities Research Council of Canada for funding support.

\section{REFERENCES}

Agreement Between the Dominion of Canada and the Province of Ontario. 1902. Government of Canada's vellum copy. James Bay Treaty No 9 - IT 438 (MIKAN No. 3987471 or R216-796-E; Volume 1851/IT438; GAD Reference number IT 438). http://ao.minisisinc.com/scripts/mwimain.dll/144/ARCH_ DESCRIPTIVE/DESCRIPTION_DET_REP/SISN\%20 22970?SESSIONSEARCH

1905. Government of Canada's vellum copy. James Bay Treaty No 9 - IT 437 (MIKAN No. 3987470 or R216-79-6-E; Volume 1851/IT437; GAD Reference number IT 437). 
Armstrong, J. 2000. A political economy of Native marginalization: A study of the appropriation of Aboriginal water rights: The case of the Mishkeegogamang First Nation. PhD dissertation, Queen's University, Kingston, Ontario.

- 2008. The elusive statement of treaty principles James Bay Treaty No. 9. NAN-Canada Treaty Discussion Forum. Ontario, Canada: Armstrong Historical Research Services, Nishnawbe Aski Nation Head Office, 100 Back St., Unit 200, Thunder Bay, Ontario P7J 1L2, Canada.

-2013. The role of Ontario in the making and implementation of Treaty Nine: The taking up clause and harvesting rights. Ontario, Canada: Armstrong Historical Research Services, Nishnawbe Aski Nation Head Office, 100 Back St.,Unit 200, Thunder Bay, Ontario P7J 1L2, Canada.

Babe, R.E. 1993. Telecommunications in Canada: Technology, industry, and government. Toronto, Ontario: University of Toronto Press.

Babin, D. 2009. G35 Standing Committee on General Government, Hearings, Bill 173 (Mining Amendment Act, 2009).

https://www.ola.org/en/legislative-business/committees/ general-government/parliament-39/transcripts/committeetranscript-2009-aug-12

Beardy, F. 2009. G35 Standing Committee on General Government, Hearings, Bill 173 (Mining Amendment Act, 2009).

https://www.ola.org/en/legislative-business/committees/ general-government/parliament-39/transcripts/committeetranscript-2009-aug-12

Beardy, S. 2009. G32 Standing Committee on General Government, Hearings, Bill 173 (Mining Amendment Act, 2009).

https://www.ola.org/en/legislative-business/committees/ general-government/parliament-39/transcripts/committeetranscript-2009-aug-06

Bernstein D.C.J. 1978. Regina v Batisse, Ontario District Court, March 9, 1978.

http://library2.usask.ca/native/cnlc/vol09/429.html

Bill C-15. 2021. United Nations Declaration on the Rights of Indigenous Peoples Act. Government of Canada.

https://parl.ca/Content/Bills/432/Government/C-15/C15_4/C-15_4.PDF

Borrows, J. 2015. Aboriginal title and private property. The Supreme Court Law Review: Osgoode's Annual Constitutional Cases Conference 71: Article 5.

http://digitalcommons.osgoode.yorku.ca/sclr/vol71/iss1/5

Calverley, D. 2006. The impact of the Hudson's Bay Company on the creation of Treaty Number Nine. Ontario History 98(1):30-51.

https://doi.org/10.7202/1065839ar

Capreol, J.L. 1907. Provincial Order-in-Council with respect to Treaty No. 9 certified by J. Capreol, Clerk, Executive Council, Government of Ontario. Treaty No. 9 - James Bay Agency Survey of Treaty No. 9: Reports, Memoranda, Diaries, Pay Sheets, Accounts (Plans, Tracings) (MIKAN No. 2072971 or R216-244-6-E; Volume 3105; File 309,350-3).
Chipman, C. 1905. C. Chipman, Commissioner, Hudson's Bay Company, letter dated June 19, 1905, to F. Pedley, Deputy Superintendent General Indian Affairs. Treaty No. 9 The James Bay Treaty - Reports, Correspondence, Drafts, Memorandums, Order in Council (MIKAN No. 2082958 or R216-244-6-E; Volume 3033; File 235,225 Part 1).

CIRNAC (Crown-Indigenous Relations and Northern Affairs Canada). 2018. Overview of a recognition and implementation of Indigenous rights framework.

https://www.rcaanc-cirnac.gc.ca/eng/1536350959665/ 1539959903708

. 2019. About recognition of Indigenous rights and selfdetermination discussion tables.

https://www.rcaanc-cirnac.gc.ca/eng/1511969222951/1529103 469169\#chp7

- 2021. Indigenous peoples and lands: Treaties, agreements and claims. Pre-1975 treaties.

https://www.rcaanc-cirnac.gc.ca/eng/1370362690208/ 1544619449449

Cochrane, F. 1905. F. Cochrane, Minister of Mines and Works, Government of Ontario, letter dated November 29, 1905, to F. Pedley, Deputy Superintendent General Indian Affairs. Treaty No. 9 The James Bay Treaty - Reports, Correspondence, Drafts, Memorandums, Order in Council (MIKAN No. 2082958 or R216-244-6-E; Volume 3033; File 235,225 Part 1).

Constitution Act, 1867. 1867. A consolidation of the Constitution Acts 1867 to 1982, Department of Justice Canada, consolidated as of January 1, 2013. Ottawa: Public Works and Government Services Canada.

https://laws-lois.justice.gc.ca/pdf/const_e.pdf

Corston, K. 2009. G35 Standing Committee on General Government, Hearings, Bill 173 (Mining Amendment Act, 2009).

https://www.ola.org/en/legislative-business/committees/ general-government/parliament-39/transcripts/committeetranscript-2009-aug-12

Department of Justice Canada. 2021. Implementing the United Nations Declaration on the Rights of Indigenous Peoples The Declaration. Ottawa: Department of Justice Canada.

https://www.justice.gc.ca/eng/declaration/about-apropos.html

Dobie, J. 1911. Surveyor letter to F. Pedley, Department of Indian Affairs (March 30, 1911) (Treaty No. 9 - James Bay Agency Survey of Treaty No. 9: Reports, Memoranda, Diaries, Pay Sheets, Accounts (Plans, Tracings) (MIKAN No. 2072971 (R216-244-6-E; Volume 3105; File 309,350-3).

. 1912. Surveyor report to J. McLean, Assistant Deputy and Secretary Indian Affairs (March 30, 1912) (Treaty No. 9 - James Bay Agency Survey of Treaty No. 9: Reports, Memoranda, Diaries, Pay Sheets, Accounts (Plans, Tracings) (MIKAN No. 2072971 (R216-244-6-E; Volume 3105; File 309,350-3).

Dominion of Canada. 1905. Official report of the debates of the House of Commons of the Dominion of Canada, First SessionTenth Parliament, 5 Edward VII, 1905, Vol. LXIX. Ottawa: S.E. Dawson, Printer to the King's Most Excellent Majesty. https://parl.canadiana.ca/view/oop.debates_HOC1001 $01 / 1$ ? $\mathrm{r}=0 \& \mathrm{~s}=1$ 
Dragland, S. 1994. Floating voice. Duncan Campbell Scott and the literature of Treaty 9. Concord, Ontario: House of Anansi Press.

Drake, K. 2018. The impact of St Catherine's milling. Law Society of Upper Canada, Special Lectures 2017. Canada at 150: The charter and the constitution. Toronto, Ontario: Law Society of Upper Canada.

https://digitalcommons.osgoode.yorku.ca/cgi/viewcontent.cgi? article $=3684 \&$ context $=$ scholarly_works

Edgar, P. 1906a. Twelve hundred miles by canoe: Among the Indians in northern waters. Canada: An Illustrated Weekly Journal for all Interested in the Dominion (November 24):255. http://www.treaty9diaries.ca/wp-content/uploads/2011/05/ Twelve-Hundred-Miles-by-Canoe.pdf

- 1906b. Twelve hundred miles by canoe. Among the Indians in northern waters. Canada: An Illustrated Weekly Journal for all Interested in the Dominion (December 22):436. http://www.treaty9diaries.ca/wp-content/uploads/2011/05/ Twelve-Hundred-Miles-by-Canoe.pdf

- 1906c. P. Edgar diary as the Treaty No. 9 secretary for the 1906 expedition written in D.C. Scott (1905) diary "Journal of James Bay Treaty Trips” 22 May-16 August 1906 (RG 10, Volume 1028).

- 1907a. Twelve hundred miles by canoe. Among the Indians in northern waters. Canada: An Illustrated Weekly Journal for all Interested in the Dominion (January 5):515-516. http://www.treaty9diaries.ca/wp-content/uploads/2011/05/ Twelve-Hundred-Miles-by-Canoe.pdf

- 1907b. Twelve hundred miles by canoe. Latchford to Matachewan. Canada: An Illustrated Weekly Journal for all Interested in the Dominion (January 19):61-62.

http://www.treaty9diaries.ca/wp-content/uploads/2011/05/ Twelve-Hundred-Miles-by-Canoe.pdf

. 1907c. Twelve hundred miles by canoe. Biscotasing to Fort Matagami. Canada: An Illustrated Weekly Journal for all Interested in the Dominion (February 2):156-157.

http:/www.treaty9diaries.ca/wp-content/uploads/2011/05/ Twelve-Hundred-Miles-by-Canoe.pdf

1907d. Twelve hundred miles by canoe. Fort Matagami. Canada: An Illustrated Weekly Journal for all Interested in the Dominion (February 16):245-246.

http://www.treaty9diaries.ca/wp-content/uploads/2011/05/ Twelve-Hundred-Miles-by-Canoe.pdf

1907e. Twelve Hundred Miles by Canoe. Flying Post and New Brunswick House. Canada: An Illustrated Weekly Journal for all Interested in the Dominion (March 2):331. http://www.treaty9diaries.ca/wp-content/uploads/2011/05/ Twelve-Hundred-Miles-by-Canoe.pdf

- 1907f. Twelve hundred miles by canoe. The homeward journey. Canada: An Illustrated Weekly Journal for all Interested in the Dominion (March 16):412-413.

http://www.treaty9diaries.ca/wp-content/uploads/2011/05/ Twelve-Hundred-Miles-by-Canoe.pdf
Fereday, J., and Muir-Cochrane, E. 2006. Demonstrating rigor using thematic analysis: A hybrid approach of inductive and deductive coding and theme development. International Journal of Qualitative Methods 5(1):80-92.

https://doi.org/10.1177/160940690600500107

Galbraith, W. 1909. Surveyor letter to Secretary, Department of Indian Affairs (Sept 30, 1909) (Treaty No. 9 - James Bay Agency Survey of Treaty No. 9: Reports, Memoranda, Diaries, Pay Sheets, Accounts (Plans, Tracings) (MIKAN No. 2072971 (R216-244-6-E; Volume 3105; File 309,350-3).

- 1910a. Diary 1909 (March 2, 1910a) (Treaty No. 9 - James

Bay Agency Survey of Treaty No. 9: Reports, Memoranda, Diaries, Pay Sheets, Accounts (Plans, Tracings) (MIKAN No. 2072971 (R216-244-6-E; Volume 3105; File 309,350-3).

1910b. Surveyor letter to Secretary, Department of Indian Affairs (March 8, 1910b) (Treaty No. 9 - James Bay Agency Survey of Treaty No. 9: Reports, Memoranda, Diaries, Pay Sheets, Accounts (Plans, Tracings) (MIKAN No. 2072971 (R216-244-6-E; Volume 3105; File 309,350-3).

Gardner, H.L., Tsuji, S.R.J., McCarthy, D.D., Whitelaw, G.S., and Tsuji, L.J.S. 2012. The Far North Act (2010) consultative process: A new beginning or the reinforcement of an unacceptable relationship in northern Ontario, Canada? International Indigenous Policy Journal 3(2). https://doi.org/10.18584/iipj.2012.3.2.7

Government of Ontario. 1905a. Draft Order-in-Council for Treaty No. 9 enclosed with letter dated June 1, 1905, from A. Matheson, Provincial Treasurer, Government of Ontario, to F. Pedley, Deputy Superintendent General Indian Affairs. Treaty No. 9 The James Bay Treaty - Reports, Correspondence, Drafts, Memorandums, Order in Council (MIKAN No. 2082958 or R216-244-6-E; Volume 3033; File 235,225 Part 1).

. 1905b. Draft Agreement was enclosed with the A. Matheson, Provincial Treasurer, Government of Ontario, letter dated June 23, 1905, to F. Pedley, Deputy Superintendent General Indian Affairs Treaty No. 9 The James Bay Treaty Reports, Correspondence, Drafts, Memorandums, Order in Council (MIKAN No. 2082958 or R216-244-6-E; Volume 3033; File 235,225 Part 1).

2019. The evolution of Ontario's boundaries 1774-1912. Toronto, Ontario: Ministry of Government and Consumer Services.

http://www.archives.gov.on.ca/en/maps/ontario-boundaries. aspx

- 2020. Orders in Council definition. Toronto, Ontario: Government of Ontario.

https://www.ontario.ca/search/orders-in-council

Hall, T. 2009. G36 Standing Committee on General Government, Hearings, Bill 173 (Mining Amendment Act, 2009).

https://www.ola.org/en/legislative-business/committees/ general-government/parliament-39/transcripts/committeetranscript-2009-aug-13

Henry, J. 2006. The Proclamation of 1763. A model for the establishment of treaties.

http://www.lac-bac.gc.ca/publications/002/015002-2010-e. html 
Hunter, G. 2009. G35 Standing Committee on General Government, Hearings, Bill 173 (Mining Amendment Act, 2009).

https:/www.ola.org/en/legislative-business/committees/ general-government/parliament-39/transcripts/committeetranscript-2009-aug-12

King, H., and Pasternak, S. 2018. Canada's emerging Indigenous rights framework: A critical analysis. Toronto, Ontario: Yellowhead Institute.

https://yellowheadinstitute.org/wp-content/uploads/2018/06/ yi-rights-report-june-2018-final-5.4.pdf

Legislative Assembly of Ontario. 2020. Elihu James Davis; Alexander Grant Mackay; James Joseph Foy; Francis Cochrane. https://www.ola.org/en/members/all/elihu-james-davis https://www.ola.org/en/members/all/alexander-grant-mackay https://www.ola.org/en/members/all/james-joseph-foy https://www.ola.org/en/members/all/francis-cochrane

LAC (Library and Archives Canada). 1905a. Order-in-Council \#1905-1065. Treaty negotiated with Indian tribes to obtain extinction of titles to lands in northern part of Province of Ontario - S.G.I.A. [Superintendent General of Indian Affairs], 1905/06/05. Ottawa: LAC.

https://www.bac-lac.gc.ca/eng/discover/politics-government/ orders-council/Pages/item.aspx?IdNumber $=124770$

- 1905b. Order-in-Council \#1905-1262. Indian lands, northern part of Ontario, extinction of Indian titles to and negotiations with Indians of those territories re. [regarding] - S.G.I.A. [Superintendent General of Indian Affairs], 1905/06/27. Ottawa: LAC.

http://www.bac-lac.gc.ca/eng/discover/politics-government/ orders-council/Pages/item.aspx?IdNumber=124967

. 1907. Order-in-Council \#1906-2499. Authority to ratify the James Bay Treaty no. 9, Ojibeways [Ojibwas], Crees and other Indians - S.G.I.A. [Superintendent General of Indian Affairs], 1906/12/03. Ottawa: LAC.

http://www.bac-lac.gc.ca/eng/discover/politics-government/ orders-council/Pages/item.aspx?IdNumber=141615

. 2019. Orders-in-Council. Ottawa: LAC.

https://www.bac-lac.gc.ca/eng/discover/politics-government/ orders-council/Pages/orders-in-council.aspx\#b

Long, J.S. 1978. Treaty No. 9: The half-breed question, 19021910. Cobalt, Ontario: Highway Book Shop.

. 1989. "No basis for argument": The signing of Treaty Nine in northern Ontario, 1905-1906. Native Studies Review 5(2):19-54.

. 1993. "The government is asking you for your land": The treaty made in 1905 at Fort Albany according to Cree oral tradition. Moose Factory, Ontario: J.S. Long.

- 2006. How the commissioners explained Treaty Number Nine to the Ojibway and Cree in 1905. Ontario History 98(1):1-29. https://doi.org/10.7202/1065838ar

2010. Treaty No. 9: Making the agreement to share the land in far northern Ontario in 1905. Montreal, Quebec: McGill-Queen's University Press.

- 2011. Treaty No. 9: D.C. Scott's accidental gift. In: Valentine, J.R., and Macaulay, M., eds. Archives of the Papers of Algonquian Conference 43:179-194.
Louttit, S. 2010. The Real Agreement as Orally Agreed to: The James Bay Treaty No. 9. PowerPoint Presentation at the Mushkegowuk Senior Management and First Nations Senior Management Meeting. Mushkegowuk Territory, Ontario: Mushkegowuk Territory.

https://www.oise.utoronto.ca/deepeningknowledge/UserFiles/ File/jamesbaytreaty9_realoralagreement.pdf

Macfarlane, D., and Kitay, P. 2016. Hydraulic imperialism: Hydroelectric development and Treaty 9 in the Abitibi region. American Review of Canadian Studies 46(3):380-397. https://doi.org/10.1080/02722011.2016.1228685

Macfarlane, D., and Watson, A. 2018. Hydro democracy: Water power and political power in Ontario. Scientia Canadensis 40(1):1-18. https://doi.org/10.7202/1048923ar

Macklem, P. 1997. The impact of Treaty 9 on natural resource development in northern Ontario. In: Asch, M., ed. Aboriginal and treaty rights in Canada: Essays on law, equity, and respect for difference. Vancouver, British Columbia: UBC Press. 97-132.

MacMartin, D.G. 1905. Treaty No. 9 diary. Daniel George W. MacMartin Collection, CA ON00239 F00149. Kingston, Ontario: Queen's University Archives.

MacMartin, D. 2015. D.G. MacMartin's 1905 Diary, intergovernmental conflict and Ontario's Treaty 9 role. MA thesis, University of Calgary, Calgary, Alberta. https://doi.org/10.11575/PRISM/25697

Macrae, J. 1901. J Macrae, Office of the Inspector of Indian Agencies and Reserves, Memorandum dated June 3, 1901, for the Superintendent General of Indian Affairs. Treaty No. 9 The James Bay Treaty - Reports, Correspondence, Drafts, Memorandums, Order in Council (MIKAN No. 2082958 or R216-244-6-E; Volume 3033; File 235,225 Part 1).

Manore, J.L. 1999. Cross-currents: Hydroelectricity and the engineering of northern Ontario. Waterloo, Ontario: Wilfred Laurier University Press. 223 p.

Matheson, A. 1905a. A Matheson, Provincial Treasurer, Government of Ontario, letter dated June 1, 1905, and enclosure (draft Order-in-Council) to F. Pedley, Deputy Superintendent General Indian Affairs. Treaty No. 9 The James Bay Treaty - Reports, Correspondence, Drafts, Memorandums, Order in Council (MIKAN No. 2082958 or R216-244-6-E; Volume 3033; File 235,225 Part 1).

1905b. A. Matheson, Provincial Treasurer, Government of Ontario, CPR Co Telegraph dated June 16, 1905, to F. Pedley, Deputy Superintendent General Indian Affairs. Treaty No. 9 The James Bay Treaty - Reports, Correspondence, Drafts, Memorandums, Order in Council (MIKAN No. 2082958 or R216-244-6-E; Volume 3033; File 235,225 Part 1).

- 1905c. A. Matheson, Provincial Treasurer, Government of Ontario, CPR Co Telegraph dated June 23, 1905, to F. Pedley, Deputy Superintendent General Indian Affairs. Treaty No. 9 The James Bay Treaty - Reports, Correspondence, Drafts, Memorandums, Order in Council (MIKAN No. 2082958 or R216-244-6-E; Volume 3033; File 235,225 Part 1). 
1905d. A. Matheson, Provincial Treasurer, Government of Ontario, letter dated June 23, 1905, to F. Pedley, Deputy Superintendent General Indian Affairs. Treaty No. 9 The James Bay Treaty - Reports, Correspondence, Drafts, Memorandums, Order in Council (MIKAN No. 2082958 or R216-244-6-E; Volume 3033; File 235,225 Part 1)/

. 1905e. A. Matheson, Provincial Treasurer, Government of Ontario, letter dated November 17, 1905, to F. Pedley, Deputy Superintendent General Indian Affairs. Treaty No. 9 The James Bay Treaty - Reports, Correspondence, Drafts, Memorandums, Order in Council (MIKAN No. 2082958 or R216-244-6-E; Volume 3033; File 235,225 Part 1).

1906. A. Matheson, Provincial Treasurer letter dated November 1, 1906, to Deputy Superintendent General Indian Affairs (S. Stewart Acting). Treaty No. 9 The James Bay Treaty - Adhesions to Treaty 9 (Map of Canada, 1912 Showing Unceded Portions, Census of Indians at Port Severn 1926, List of Indians Trading at Fort Hope 1926, Fort Hope Outposts, Winisk, Attawapiskot [sic]) (MIKAN No. 2083404 or (R216244-6-E; Volume 3033; File 235,225 Part 1A).

McGee, J. 1905. J. McGee Clerk of the Privy Council of Canada correspondence (Order-in-Council \#: 1905-1065) dated June 9, 1905. Treaty No. 9 The James Bay Treaty - Reports, Correspondence, Drafts, Memorandums, Order in Council (MIKAN No. 2082958 or R216-244-6-E; Volume 3033; File 235,225 Part 1).

McKay, S. 2009. G34 Standing Committee on General Government, Hearings, Bill 173 (Mining Amendment Act, 2009).

https:/www.ola.org/en/legislative-business/committees/ general-government/parliament-39/transcripts/committeetranscript-2009-aug-11

McLean, J. 1901. J. McLean, Secretary Indian Affairs, memorandum dated June 18, 1901, to R. Rimmer, Law Clerk, Indian Affairs. Treaty No. 9 The James Bay Treaty - Reports, Correspondence, Drafts, Memorandums, Order in Council (MIKAN No. 2082958 or R216-244-6-E; Volume 3033; File 235,225 Part 1).

1905. J. McLean, Secretary, Indian Affairs letter dated December 18, 1905, to J. Pope, Under Secretary of State, Government of Canada. Treaty No. 9 The James Bay Treaty - Reports, Correspondence, Drafts, Memorandums, Order in Council (MIKAN No. 2082958 or R216-244-6-E; Volume 3033; File 235,225 Part 1).

- 1911. J McLean, Assistant Deputy and Secretary Indian Affairs, letter dated April 11, 1911 to S Dobie, Ontario \& Dominion Land Surveyor. Treaty No. 9 - James Bay Agency Survey of Treaty No. 9: Reports, Memoranda, Diaries, Pay Sheets, Accounts (Plans, Tracings) (MIKAN No. 2072971 or R216-244-6-E; Volume 3105; File 309,350-3).

Ministry of Government and Consumer Services. 2020. Ontario, Office of the Commissioner of Crown Lands; Ontario, Department of Crown Lands; Ontario, Department of Lands and Mines, Office of the Minister.

https://lop.parl.ca/sites/ParlInfo/default/en_CA/People/ Profile?personId $=5682$
Moose Cree First Nation. 2009. Lower Mattagami River Hydroelectric Complex Project: Comprehensive study report. Prepared by Ontario Power Generation Inc. and Moose Cree First Nation for Fisheries and Oceans Canada.

www.ceaa-acee.gc.ca/050/documents_staticpost/ 26302/38969E.pdf

Morrison, J. 1986. Treaty research report - Treaty No. 9 (19051906). Ottawa, Ontario: Treaties and Historical Research Centre, Indian and Northern Affairs Canada.

https://www.rcaanc-cirnac.gc.ca/eng/1100100028859/ 1564415209671

- 1988. The poet and the Indians. Duncan Campbell Scott woos the muse and negotiates Treaty Number Nine. The Beaver August-September 1988:4-16.

Mushkegowuk Council. 2021. Sharing the land: A Mushkegowuk treaty awareness initiative.

http://www.mushkegowuk.com/?page_id $=4008$

Newcombe, E. 1905a. E. Newcombe, Deputy Minister of Justice, Government of Canada, letter dated May 5, 1905, to F. Pedley, Deputy Superintendent General Indian Affairs. Treaty No. 9 The James Bay Treaty - Reports, Correspondence, Drafts, Memorandums, Order in Council (MIKAN No. 2082958 or R216-244-6-E; Volume 3033; File 235,225 Part 1).

- 1905b. E. Newcombe, Deputy Minister of Justice, Government of Canada, letter dated June 26, 1905, with the revised draft Agreement enclosed, to F. Pedley, Deputy Superintendent General Indian Affairs. Treaty No. 9 The James Bay Treaty - Reports, Correspondence, Drafts, Memorandums, Order in Council (MIKAN No. 2082958 or R216-244-6-E; Volume 3033; File 235,225 Part 1).

Obosawin, A. 2014. Trick of treaty? The James Bay Treaty Treaty No. 9. Film.

https://www.nfb.ca/film/trick_or_treaty/

Oliver, F. 1905. F. Oliver, Minister of the Interior, and Superintendent General Indian Affairs, submission of the Agreement on June 27, 1905, to the Governor General in Council, Government of Canada. Treaty No. 9 The James Bay Treaty - Reports, Correspondence, Drafts, Memorandums, Order in Council (MIKAN No. 2082958 or R216-244-6-E; Volume 3033; File 235,225 Part 1).

Ontario. 1914. Canada (Ontario) Boundary Act, 1889. Ontario: Revised Statutes: Vol. 1914: Iss. 3, Article 8.

https://digitalcommons.osgoode.yorku.ca/rso/vol1914/iss3/8

- 1980. Ontario Boundaries Extension Act (Can., 1912). Vol. 1980: Iss. 9, Article 28.

http://igitalcommons.osgoode.yorku.ca/rso/vol1980/iss9/28

Parliament of Canada. 2020. Parliamentarians. Clifford Sifton, Wilfrid Laurier, and Frank Oliver.

https://lop.parl.ca/sites/ParlInfo/default/en_CA/People/ parliamentarians

Pedley, F. 1903. F. Pedley, Deputy Superintendent General Indian Affairs, Memorandum (final version) dated August 17, 1903, to C. Sifton, Minister of the Interior, and Superintendent General Indian Affairs. Treaty No. 9 The James Bay Treaty - Reports, Correspondence, Drafts, Memorandums, Order in Council (MIKAN No. 2082958 or R216-244-6-E; Volume 3033; File 235,225 Part 1). 
1904a. F. Pedley, Deputy Superintendent General Indian Affairs, letter dated April 30, 1904, to E. Davis, Commissioner of Crown Lands, Government of Ontario. Treaty No. 9 The James Bay Treaty - Reports, Correspondence, Drafts, Memorandums, Order in Council (MIKAN No. 2082958 or R216-244-6-E; Volume 3033; File 235,225 Part 1).

1904b. F. Pedley, Deputy Superintendent General Indian Affairs, memorandum dated June 10, 1904. Treaty No. 9 The James Bay Treaty - Reports, Correspondence, Drafts, Memorandums, Order in Council (MIKAN No. 2082958 or R216-244-6-E; Volume 3033; File 235,225 Part 1).

1904c. F. Pedley, Deputy Superintendent General Indian Affairs letter dated June 24 (but difficult to read because the date has been written over), 1904, to A. White, Assistant Commissioner of Crown Lands, Government of Ontario. Treaty No. 9 The James Bay Treaty - Reports, Correspondence, Drafts, Memorandums, Order in Council (MIKAN No. 2082958 or R216-244-6-E; Volume 3033; File 235,225 Part 1).

. 1905a. F. Pedley, Deputy Superintendent General Indian

Affairs letter dated February 27, 1905, to A. White, Assistant Commissioner of Crown Lands, Government of Ontario. Treaty No. 9 The James Bay Treaty - Reports, Correspondence, Drafts, Memorandums, Order in Council (MIKAN No. 2082958 or R216-244-6-E; Volume 3033; File 235,225 Part 1).

- 1905b. F. Pedley, Deputy Superintendent General Indian Affairs, The Great North Western Telegraph Company of Canada, dated March 18, 1905, to A. White, Assistant Commissioner of Crown Lands, Government of Ontario. Treaty No. 9 The James Bay Treaty - Reports, Correspondence, Drafts, Memorandums, Order in Council (MIKAN No. 2082958 or R216-244-6-E; Volume 3033; File 235,225 Part 1).

. 1905c. F. Pedley, Deputy Superintendent General Indian

Affairs, memorandum dated April 27, 1905, entitled "In Re James Bay Treaty" to Sir Wilfred Laurier, Prime Minister of Canada, and Acting Superintendent General Indian Affairs. Treaty No. 9 The James Bay Treaty - Reports, Correspondence, Drafts, Memorandums, Order in Council (MIKAN No. 2082958 or R216-244-6-E; Volume 3033; File 235,225 Part 1).

1905d. F. Pedley, Deputy Superintendent General Indian Affairs, letter dated May 2, 1905, and enclosure to E. Newcombe, Deputy Minister of Justice, Government of Canada. Treaty No. 9 The James Bay Treaty - Reports, Correspondence, Drafts, Memorandums, Order in Council (MIKAN No. 2082958 or R216-244-6-E; Volume 3033; File 235,225 Part 1).

1905e. F. Pedley, Deputy Superintendent General Indian Affairs, letter dated May 8, 1905, and enclosure to J. Foy, Commissioner of Crown Lands, Government of Ontario. Treaty No. 9 The James Bay Treaty - Reports, Correspondence, Drafts, Memorandums, Order in Council (MIKAN No. 2082958 or R216-244-6-E; Volume 3033; File 235,225 Part 1).

1905f. F Pedley Memorandum dated June 2, 1905, to Sir Wilfred Laurier, Department of Indian Affairs, Ottawa [Ontario, Canada]. Treaty No. 9 The James Bay Treaty Reports, Correspondence, Drafts, Memorandums, Order in Council (MIKAN No. 2082958 or R216-244-6-E; Volume 3033; File 235,225 Part 1). 1905g. F. Pedley, Deputy Superintendent General Indian Affairs, Memorandum dated June 3, 1905, to Sir Wilfrid Laurier, Prime Minister of Canada. Treaty No. 9 The James Bay Treaty - Reports, Correspondence, Drafts, Memorandums, Order in Council (MIKAN No. 2082958 or R216-244-6-E; Volume 3033; File 235,225 Part 1).

1905h. F. Pedley, Deputy Superintendent General Indian Affairs, letter dated June 16, 1905, to A. Matheson, Provincial Treasurer, Government of Ontario. Treaty No. 9 The James Bay Treaty - Reports, Correspondence, Drafts, Memorandums, Order in Council (MIKAN No. 2082958 or R216-244-6-E; Volume 3033; File 235,225 Part 1).

1905i. F. Pedley, Deputy Superintendent General Indian Affairs, letter dated June 5, 1905, to A Matheson, Provincial Treasurer, Government of Ontario. Treaty No. 9 The James Bay Treaty - Reports, Correspondence, Drafts, Memorandums, Order in Council (MIKAN No. 2082958 or R216-244-6-E; Volume 3033; File 235,225 Part 1).

1905j. F. Pedley, Deputy Superintendent General Indian Affairs, letter dated June 12, 1905, to A. Matheson, Provincial Treasurer, Government of Ontario. Treaty No. 9 The James Bay Treaty - Reports, Correspondence, Drafts, Memorandums, Order in Council (MIKAN No. 2082958 or R216-244-6-E; Volume 3033; File 235,225 Part 1).

. 1905k. F. Pedley, Deputy Superintendent General Indian Affairs, CPR Co Telegraph dated June 15, 1905, to A. Matheson, Provincial Treasurer, Government of Ontario. Treaty No. 9 The James Bay Treaty - Reports, Correspondence, Drafts, Memorandums, Order in Council (MIKAN No. 2082958 or R216-244-6-E; Volume 3033; File 235,225 Part 1).

19051. F. Pedley, Deputy Superintendent General Indian

Affairs, CPR Co Telegraph dated June 16, 1905, to A. Matheson, Provincial Treasurer, Government of Ontario. Treaty No. 9 The James Bay Treaty - Reports, Correspondence, Drafts, Memorandums, Order in Council (MIKAN No. 2082958 or R216-244-6-E; Volume 3033; File 235,225 Part 1).

$1905 \mathrm{~m}$. F. Pedley, Deputy Superintendent General Indian Affairs, letter dated June 23, 1905, to A. Matheson, Provincial Treasurer, Government of Ontario. Treaty No. 9 The James Bay Treaty - Reports, Correspondence, Drafts, Memorandums, Order in Council (MIKAN No. 2082958 or R216-244-6-E; Volume 3033; File 235,225 Part 1).

- 1905n. F. Pedley, Deputy Superintendent General Indian Affairs letter dated June 24, 1905, to E. Newcombe, Deputy Minister of Justice, Government of Canada. Treaty No. 9 The James Bay Treaty - Reports, Correspondence, Drafts, Memorandums, Order in Council (MIKAN No. 2082958 or R216-244-6-E; Volume 3033; File 235,225 Part 1).

- 1905o. F. Pedley, Deputy Superintendent General Indian Affairs, Memorandum dated June 26, 1905, RE Treaty No. 9. Treaty No. 9 The James Bay Treaty - Reports, Correspondence, Drafts, Memorandums, Order in Council (MIKAN No. 2082958 or R216-244-6-E; Volume 3033; File 235,225 Part 1). 
1905p. F. Pedley, Deputy Superintendent General Indian Affairs, letter dated July 14, 1905, to A. Matheson, Provincial Treasurer, Government of Ontario. Treaty No. 9 The James Bay Treaty - Reports, Correspondence, Drafts, Memorandums, Order in Council (MIKAN No. 2082958 or R216-244-6-E; Volume 3033; File 235,225 Part 1).

. 1905q. F. Pedley, Deputy Superintendent General Indian Affairs, letter dated October 16, 1905, to F. Cochrane, Minister of Mines and Works, Government of Ontario. Treaty No. 9 The James Bay Treaty - Reports, Correspondence, Drafts, Memorandums, Order in Council (MIKAN No. 2082958 or R216-244-6-E; Volume 3033; File 235,225 Part 1).

1905r. F. Pedley, Deputy Superintendent General Indian Affairs, letter dated November 25, 1905, to F. Cochrane, Minister of Mines and Works, Government of Ontario. Treaty No. 9 The James Bay Treaty - Reports, Correspondence, Drafts, Memorandums, Order in Council (MIKAN No. 2082958 or R216-244-6-E; Volume 3033; File 235,225 Part 1).

. 1905s. F. Pedley, Deputy Superintendent General Indian Affairs, letter dated December 1, 1905, to A. Matheson, Provincial Treasurer, Government of Ontario. Treaty No. 9 The James Bay Treaty - Reports, Correspondence, Drafts, Memorandums, Order in Council (MIKAN No. 2082958 or R216-244-6-E; Volume 3033; File 235,225 Part 1).

Rimmer, R. 1901. Proposed New Treaty in Ontario and Quebec Report by Mr. Rimmer, Law Clerk, Indian Affairs, Opinion dated June 24, 1901. Treaty No. 9 The James Bay Treaty Reports, Correspondence, Drafts, Memorandums, Order in Council (MIKAN No. 2082958 or R216-244-6-E; Volume 3033; File 235,225 Part 1).

Royal Proclamation of 1763. 1763. Ottawa: CIRNAC.

https://www.rcaanc-cirnac.gc.ca/eng/1379594359150/1607905 375821?wbdisable $=$ true

Scott, D.C. 1905a. D. Scott, Accountant, Indian Affairs, Memorandum dated March 18, 1905, to F. Pedley, Deputy Superintendent General Indian Affairs. Treaty No. 9 The James Bay Treaty - Reports, Correspondence, Drafts, Memorandums, Order in Council (MIKAN No. 2082958 or R216-244-6-E; Volume 3033; File 235,225 Part 1).

1905b. D.C. Scott, Accountant, Indian Affairs, Memorandum dated June 29, 1905, to F. Pedley, Deputy Superintendent General Indian Affairs. Treaty No. 9 The James Bay Treaty - Reports, Correspondence, Drafts, Memorandums, Order in Council (MIKAN No. 2082958 or R216-244-6-E; Volume 3033; File 235,225 Part 1).

1905c. "Journal of James Bay Treaty Trips" 30 June-6 September 1905. 38 p. (RG 10, Volume 1028).

. 1906. The last of the Indian treaties. Scribner's Magazine 40:573-583.

Scott, D.C., Stewart, S., and MacMartin, D.G. 1905. James Bay Treaty No. 9 - November 6, 1905. Ottawa, Ontario, Canada: Government Printing Bureau, 1907. Treaty No. 9 - James Bay Treaty - Annuity interest payments and accounts (MIKAN No. 2083329 or R216-244-6-E; Volume 3034 File Part 4; File 235,225).
1906. The James Bay Treaty-Treaty No. 9. (Made in 1905 and 1906) and Adhesions made in 1929 and 1930. Reprinted from the edition of 1931 by Roger Duhamel, Queen's Printer and Controller of Stationary, Ottawa, Ontario, 1964. Cat. No. Ci 72-0964.

Sholdice, M.M. 2019. The Ontario experiment: Hydroelectricity, public wwnership, and transnational progressivism, 19061939. PhD dissertation, University of Guelph, Guelph, Ontario.

Solomon, A. 2009. G35 Standing Committee on the General Government, Hearings, Bill 173 (Mining Amendment Act, 2009).

https://www.ola.org/en/legislative-business/committees/ general-government/parliament-39/transcripts/committeetranscript-2009-aug-12

Solomon, J. 2009. G35 Standing Committee on the General Government, Hearings, Bill 173 (Mining Amendment Act, 2009).

https://www.ola.org/en/legislative-business/committees/ general-government/parliament-39/transcripts/committeetranscript-2009-aug-12

Stewart, S. 1905a. S Stewart, Assistant Secretary, Indian Affairs, letter dated June 26, 1905, to Undersecretary of State, Government of Canada, Ottawa, Ontario. Treaty No. 9 The James Bay Treaty - Reports, Correspondence, Drafts, Memorandums, Order in Council (MIKAN No. 2082958 or R216-244-6-E; Volume 3033; File 235,225 Part 1).

. 1905b. The James Bay Treaty: Treaty 9. 175 p.

http://www.treaty9diaries.ca/wp-content/uploads/2011/05/ Stewart-Diary-1905.pdf

1906. The James Bay Treaty: Indians dealt with by the Commissioners during summer of 1906. $131 \mathrm{p}$.

http:/www.treaty9diaries.ca/wp-content/uploads/2011/05/ Stewart-Diary-1906.pdf

Titley E.B. 1986. A narrow vision: Duncan Campbell Scott and the administration of Indian Affairs in Canada. Vancouver, British Columbia: UBC Press.

Treaty No. 9. 1905. James Bay Treaty No. 9. Government of Canada's vellum copy (MIKAN No. 3987469 or R216-79-6-E; Volume 1851/IT436; GAD Reference number IT 436). http://ao.minisisinc.com/scripts/mwimain.dll/144/ARCH DESCRIPTIVE/DESCRIPTION_DET_REP/SISN\%20 22970?SESSIONSEARCH

1907. The James Bay Treaty-Treaty No. 9. Treaty No. 9James Bay Treaty - Annuity Interest Payments and Accounts (MIKAN No. 2083329 or R216-244-6-E; Volume 3034; File 235,225 Part 4). Ottawa: Government Printing Bureau.

_ 1964. The James Bay Treaty-Treaty No. 9 (Made in 1905 and 1906) and Adhesions made in 1929 and 1930. Reprinted from the edition of 1931 by Roger Duhamel. Queens Printer and Controller of Stationary, Ottawa. Cat No. Ci 72-0964.

—. Undated. The James Bay Treaty-Treaty No. 9. Typeset printed copy with manuscript corrections of James Bay Treaty No. 9 - IT 440 (MIKAN No. 3987474 or R216-79-6-E; Volume 1851/IT440; GAD Reference Number IT 440).

Tsuji, L.J.S., and Ho, E. 2002. Traditional environmental knowledge and Western science: In search of common ground. Canadian Journal of Native Studies 22(2):327-360. 
Tsuji, L.J.S., and Nieboer, E. 1999. A question of sustainability in Cree harvesting practices: The seasons, technological and cultural changes in the western James Bay region of northern Ontario, Canada. Canadian Journal of Native Studies 19(1):169-192.

Tsuji, L.J.S., and Tsuji, S.R.J. 2021. Development on Indigenous homelands and the need to get back to basics with scoping: Is there still "unceded" land in northern Ontario, Canada, with respect to Treaty No. 9 and its adhesions? International Indigenous Policy Journal 12(1). https://doi.org/10.18584/iipj.2021.12.1.8551

Tsuji, L.J.S., Gomez, N., Mitrovica, J.X., and Kendall, R. 2009. Post-glacial isostatic adjustment and global warming in Subarctic Canada: Implications for islands of the James Bay region Arctic 62(4):458-467.

https://doi.org/10.14430/arctic176

Tsuji, L.J.S., McCarthy, D.D., Whitelaw, G.S., and McEachren, J. 2011. Getting back to basics: The Victor Diamond Mine environmental assessment scoping process and the issue of family-based traditional lands versus registered traplines. Impact Assessment and Project Appraisal 29(1):37-47. https://doi.org/10.3152/146155111X12913679730755

Tsuji, L.J.S., Daradich, D., Gomez, N., Hay, C., and Mitrovica, J.X. 2016. Sea level change in the western James Bay region of Subarctic Ontario: Emergent land and implications for Treaty No. 9. Arctic 69(1):99-107.

https://doi.org/10.14430/arctic4542
Tsuji, L.J.S., General, Z., Tsuji, S.R.J., Powell, E., Latychev, K., Clark, J., and Mitrovica, J.X. 2020a. Akimiski Island, Nunavut, Canada: The use of Cree https://doi.org/10.14430/arctic71481 Aboriginal title. Arctic 73(4):421-432. https://doi.org/10.14430/arctic71481

Tsuji, L.J.S., Tsuji, S.R.J., Zuk, A.M., Davey, R., and Liberda, E.N. 2020b. Harvest programs in First Nations of Subarctic Canada: The benefits go beyond addressing food security and environmental sustainability issues. International Journal of Environmental Research and Public Health 17(21): 8113. https://doi.org/10.3390/ijerph17218113

White, A. 1904a. A. White, Assistant Commission Crown Lands, Government of Ontario, letter dated May 7, 1904, to F. Pedley, Deputy Superintendent General Indian Affairs. Treaty No. 9 The James Bay Treaty - Reports, Correspondence, Drafts, Memorandums, Order in Council (MIKAN No. 2082958 or R216-244-6-E; Volume 3033; File 235,225 Part 1).

- A. White, Assistant Commissioner of Crown Lands, Government of Ontario, letter dated May 30, 1904, to F. Pedley, Deputy Superintendent General Indian Affairs. Treaty No. 9 The James Bay Treaty - Reports, Correspondence, Drafts, Memorandums, Order in Council (MIKAN No. 2082958 or R216-244-6-E; Volume 3033; File 235,225 Part 1).

Whitelaw G.S., McEachren J, McCarthy D.D., and Tsuji L.J.S. 2012. The use of traditional environmental knowledge to resolve the issue of family-based traditional lands versus registered traplines: The Victor Diamond Mine comprehensive environmental assessment scoping process. Canadian Journal of Native Studies 32(2):141-158. 